\title{
Poverty, Social Divisions, and Conflict in Nepal*
}

\author{
Quy-Toan Do† $\quad$ Lakshmi Iyer $\ddagger$
}

\begin{abstract}
We conduct an econometric analysis of the economic and social factors that contributed to the spread of violent conflict in Nepal. We find that conflict intensity is significantly higher in places with greater poverty and lower levels of economic development. Violence is higher in locations that favor insurgents, such as mountains and forests. We find weaker evidence that caste divisions or linguistic diversity in society are correlated with the intensity of civil conflict.
\end{abstract}

Keywords: violent conflict, poverty, social polarization

World Bank Policy Research Working Paper 4228, May 2007

The Policy Research Working Paper Series disseminates the findings of work in progress to encourage the exchange of ideas about development issues. An objective of the series is to get the findings out quickly, even if the presentations are less than fully polished. The papers carry the names of the authors and should be cited accordingly. The findings, interpretations, and conclusions expressed in this paper are entirely those of the authors. They do not necessarily represent the view of the World Bank, its Executive Directors, or the countries they represent. Policy Research Working Papers are available online at http://econ.worldbank.org.

*We thank the Informal Sector Service Centre (INSEC, Nepal) for data on conflictrelated deaths. We thank Shawn Cole, Elena Glinskaya, Simon Johnson, Miguel Messmacher, Martin Ravallion, Debraj Ray, Eric Werker, Hassan Zaman and seminar participants at the World Bank, Harvard Business School, the Workshop on Endogenous Institutions and Political Conflict (UC Berkeley) and NEUDC 2006 for comments and suggestions. Tripti Thapa provided outstanding research assistance.

†Research Department, World Bank. qdo@worldbank.org ‡Corresponding author. Harvard Business School. liyer@hbs.edu 


\section{Introduction}

Since 1945, more than 70 civil wars have occurred around the world, resulting in approximately 20 million deaths and displacing more than 67 million people. ${ }^{1}$ Understanding the causes of the onset and continuation of such conflicts is therefore of great importance, and the analysis of the determinants of civil conflict has been the subject of a recent and growing literature in economics. ${ }^{2}$ There have been several cross-country studies of the proximate correlates of civil war: Collier and Hoeffler (2004) and Fearon and Laitin (2003) both find that poorer countries face a greater risk of civil conflict. Miguel et al. (2004) use instrumental variable analysis to corroborate this view that lower economic growth leads to more conflict. However, this finding is subject to varying interpretations: while Collier and Hoeffler (2004) interpret poverty as proxying for the opportunity cost of rebel recruitment, Fearon and Laitin (2003) emphasize the lack of state capacity in poor countries. These studies also differ in their findings on the impact of other factors: Collier and Hoeffler find that civil conflicts are more likely in countries which are dominated by one ethnic group and which have a larger stock of easily expropriated primary commodities, while the other two studies find no impact of ethnic divisions or primary commodities on the likelihood of conflict.

The results from cross-country studies are subject to the caveat that civil conflict in one country might have very different causes and characteristics than conflict in another. ${ }^{3}$ Further, the data on civil conflicts and other variables may not be strictly comparable across countries (Sambanis, 2004). There have been a few within-country studies of civil conflict. Barron et al. (2004) examine village-level conflicts in Indonesia, while Deininger (2004) examines the causes and consequences of civil strife in Uganda. However, both these studies focus on a local level of conflict and construct measures of conflict based on subjective interviews. They do not study organized conflict like insurgencies or civil wars, and hence are not strictly comparable to the cross-country studies. The set of case studies in Collier and Sambanis (2005)

\footnotetext{
${ }^{1}$ Collier and Sambanis (2005) pp xiii.

${ }^{2}$ See Humphreys (2003) for a review of this literature.

${ }^{3}$ Sambanis (2001) analyses ethnic and non-ethnic conflicts separately and finds that they have somewhat different causes.
} 
provide richer and more detailed within-country qualitative studies to complement the crosscountry large-sample studies; however, they are not strictly comparable to the cross-country regression-based analyses.

Our study examines violent conflict within one country, Nepal, and applies the crosscountry regression methodology to a within-country context. This approach mitigates many of the concerns regarding cross-country analysis: first, since we are able to study the spread of the same conflict to different parts of the country, several variables which differ across countries such as the existing political system, the aims of the rebel movement or the involvement of other countries, are held constant in such a study. One implication of such approach is that we are not able to examine the impact of these factors, which can be quite important in many contexts. However, these variables are typically not controlled for in many cross-country analyses of conflict. ${ }^{4}$ Second, we are able to construct finer measures of conflict intensity based on the number of casualties and other human rights abuses, rather than just using a dummy variable for whether an area experiences conflict or not. Third, we are also able to separately analyze conflict-related deaths caused by activist forces and by the state, and study the evolution of the conflict intensity over time (cross-country studies usually do not go further than dating the onset and end of civil wars). Fourth, we go beyond existing empirical analyses of the conflict in Nepal (Murshed and Gates, 2005; Bohara et al., 2006; Acharya, 2007) by constructing detailed measures of social divisions, based both on caste and linguistic diversity in the country, and by focusing on the role of poverty.

Starting in 1996, Nepal was affected by the "People's War" started by Maoist activists, whose main aim was to establish a republic and change the Constitution. The activists used guerilla warfare techniques to attack government facilities and officials. This conflict spread to all parts of the country, and resulted in a death toll of more than 13,000 people nationwide. Large parts of rural Nepal were under the control of the activists, though the district headquarters remained under the control of the state. In 2006, the Maoists began peace talks with the government.

\footnotetext{
${ }^{4}$ An exception is Sambanis (2001), which examines the role of neighboring country characteristics on civil war incidence.
} 
In our empirical analysis, we consider a wide range of economic and social variables which are hypothesized to affect the likelihood of violent conflict, including geographic characteristics, economic development, social diversity and government investment in infrastructure. We find that geographic conditions (presence of mountains and forests) explain a quarter of the cross-district variation in conflict intensity. Controlling for geography, the lack of economic opportunities, measured by higher poverty or lower literacy rates, is significantly and robustly associated with a higher intensity of violent conflict: a 10 percentage point increase in poverty is associated with 23-25 additional conflict-related deaths. Poverty is significantly associated both with the onset of the conflict, as well as its continuation. However, this relationship is not constant over time: both state forces and Maoist activists inflict the greatest casualties in the poorest areas in 2002, when the conflict escalated. As the activists gained control of the poorest areas over time, the highest levels of conflict-related deaths were experienced in the somewhat better-off areas. There is some evidence that greater social polarization (measured by the caste diversity of Nepalese society) is associated with higher levels of conflict. However, this relationship is much less robust than the relationship with poverty; in fact, part of this relationship appears to be due to the fact that social polarization contributes to greater poverty, perhaps by limiting access to economic opportunities for the lower castes. Measures of linguistic polarization or fractionalization have no significant impact on conflict intensity.

The paper is structured as follows: Section 2 provides a brief description of the "People's War" in Nepal, section 3 describes the main hypotheses we examine and the related literature on the Nepalese conflict. Section 4 describes our data and empirical strategy, section 5 summarizes our findings and section 6 concludes.

\section{The Maoist "People's War" in Nepal}

Nepal is a poor country with a population of 27 million and a per capita GDP of $\$ 270$ in 2005. As of $2004,31 \%$ of the population lived under the poverty line. The country is located between India and China, is land-locked and has few natural resources. Agriculture is the 
major driver of the economy, contributing $40 \%$ of GDP in 2005, and employing two-thirds of the workforce. ${ }^{5,6}$ A large number of Nepalis have migrated to other countries in search of economic opportunities and remittances constituted 12\% of GDP in 2004. Politically, Nepal was a monarchy till 1990, when widespread protests led to the establishment of a multi-party democracy. The first parliamentary elections were held in 1991, and two further general elections were conducted in 1994 and 1999. Even though the Nepalese Congress obtained a majority in the elections of 1991 and 1999, Nepal has faced considerable political instability and governments have been short-lived. Since 1991, there have been 12 governments in as many years.

The Maoist insurgency was started on February 13, 1996, by members of the Communist Party of Nepal-Maoist (CPN-M), with an attack on a police post at Halleri in Rolpa district of Western Nepal. The genesis of the insurgency in the districts of Rolpa and Rukum has been attributed to several factors, including the poverty and general underdevelopment of the area, long-standing grievances against the government (for banning the cultivation of hashish in the 1970s, and the crackdown on CPN-M activists during 1994, among other issues), and a long-standing presence of Communist activists in the area (Gersony, 2003). Since 1996, this "People's War" has spread to most other districts of Nepal, with 73 out of 75 districts reporting casualties in 2004. The Maoists have carried out several attacks on army barracks, police posts, village council buildings and banks.

The chief objectives of the activist movement were to establish a people's republic and set up a constituent assembly to draft a new constitution. In particular, this would mean curtailing some or all of the existing powers of the monarchy. The 75 point manifesto released by the Maoists in November 2001 listed several other aims, including the distribution of land to poor and landless people, equal treatment for all castes and languages, and equal rights for women. Despite being named after Chairman Mao, the activists' activities have been condemned by the Chinese government, and there is no evidence that the activists enjoyed any support from China (Raj, 2004). However, they were believed to have established links with

\footnotetext{
${ }^{5}$ Nepal Data Profile 2005, the World Bank.

${ }^{6} 2001$ Census.
} 
similar activist groups in India; the 75 point manifesto promised to support all groups fighting against "Indian expansionism". Estimates of the size of the activist forces varied widely from 7,000-10,000 (Bray et al, 2003) to 10,000-15,000 (BBC report). They were mainly financed by armed raids on banks, as well as taxes on the local population and remittances from abroad. The Maoists were reported to have set up local governments and local courts in some of the areas under their control.

In the first few years of the insurgency, the response from the government was to use the existing law and order framework to address the problem; more than 1000 people were reported to have been arrested and tortured by the government in 1999 (INSEC, 1999). In several areas, the state attempted to suppress activist activity: the graph in Figure 1 shows that in 1998 and 1999, more people were killed by the state than by the Maoist activists. The political situation changed dramatically in 2001. In June 2001, Crown Prince Dipendra allegedly killed his father King Birendra and most members of his immediate family, including himself. His uncle, Gyanendra, succeeded to the throne. The then Prime Minister Sher Bahadur Deuba declared a truce with the Maoists and a first round of talks was held. However, the Maoists unilaterally broke the cease-fire in November 2001, when they simultaneously attacked army barracks in the mid-western region (Dang) as well as the eastern region (Salleri). Deuba then imposed a state of emergency, declared the Maoists to be a terrorist group, and mobilized the Royal Nepal Army to counter the insurgency. The intensity of the conflict escalated sharply after this, with more than 3,000 people being killed by the state forces in the next year (see Figure 1).

In addition to the insurgency, political instability continued throughout 2002: Prime Minister Deuba dissolved the House of Representatives in May 2002 when he could not get their support to extend the state of emergency. He was in turn dismissed by King Gyanendra in October 2002, for failing to hold fresh elections in the stipulated six-month period after dissolution of parliament. Another cease-fire agreement with the Maoists was reached in January 2003, and fresh talks began in April. However, the Maoists again broke the cease-fire in August 2003, citing the government's failure to consider their demand for a new Constituent Assembly. Violent conflict resumed, and the Maoists extended their attention to urban areas 
as well, blockading Kathmandu for several days in August 2004.

In February 2005, in the face of growing attacks by Maoist activists, King Gyanendra dismissed the Prime Minister, placed major political figures under arrest and seized power. This move and the subsequent curtailment of civil liberties in Nepal was sharply criticized by several nations, including the United States and India. In September 2005, the Maoists declared a unilateral cease-fire, which was reciprocated by the government. The Maoist activists began talks with seven major political parties in November 2005 in an attempt to present a common front against the monarchy. In April 2006, King Gyanendra gave up absolute power and called on the seven-party coalition to designate a Prime Minister and organize elections. The King then ceased to be the commander-in-chief of the army, and Nepal was declared a secular state. By November 2006, the Maoists had signed a peace deal with the seven-party coalition, ending the decade-long war. The Maoists have now joined the seven-party coalition in an interim legislature while preparing for upcoming elections to a Constituent Assembly that is expected to take place in June 2007.

The total number of casualties claimed by the "People's War" amounts to more than 13,000. There is considerable variation in the intensity of conflict in different regions of Nepal. The number of casualties is highest in the mid-Western region where the conflict began, with more than 4,000 deaths between February 1996 and December 2004. In contrast, the Eastern Development region has suffered less than 1,500 casualties in the same period. The map in Figure 2 shows this variation in the intensity of the conflict, while Figure 3 shows the spread of conflict over time. The next section considers some hypotheses about which areas might be more prone to civil conflict.

\section{Possible causes of civil conflict}

There is some diversity of views regarding the causes of the conflict in Nepal. Some reports and studies have suggested that the Maoist conflict has found support from the oppressed lower castes (Bray et al., 2003), portraying the insurgency as stemming from "rage against a 
long legacy of oppression based on caste and ethnicity" (Sengupta, 2005). Deraniyagala (2005) and Murshed and Gates (2005) focus on landlessness and relative deprivation as proximate correlates of the conflict, while Macours (2006) documents the relationship between increasing inequality and the number of abductions by the Maoists. ${ }^{7}$ However, other accounts such as Thapa and Sijapati (2004) attribute the conflict mostly to poverty and underdevelopment of the country. In an interview-based approach, Gersony (2003) finds that caste and ethnic divisions are not a major contributor to the conflict. There is also the possibility that government repression might have generated further grievances which led to greater support for the Maoist activists. Examples include the crackdown against CPN-M political activists as part of a highly contentious police operation (Operation Romeo) in the districts of Rolpa and Rukum in 1994.

Collier and Hoeffler (1998) suggest an economic framework for the general causes of civil conflict: in their view, conflict is most likely where economic gains are high, and opportunity costs are low. This framework suggests the following hypotheses: first, a higher per capita income or better job prospects should reduce the risk of insurgency, since these increase the opportunity costs of joining the activists, and hence the wages activists need to pay to recruit people to their ranks. Second, conflict is higher where there are easily expropriable resources such as low-weight high-value primary commodities (metals, drugs, precious stones) or where rents from immovable assets (e.g. oil resources) can be easily extracted. They find some support for their framework in cross-country regression analysis; however, the pure "opportunity cost" view of natural resources has been challenged and further refined both by case studies (Collier and Sambanis, 2005) and by more detailed regression analysis (Humphreys, 2005).

Fearon (2005) presents an alternative model of insurgency and state response, in which the link with poverty happens through much more indirect channels, since a lower opportunity cost also means lower gains from winning the conflict. Fearon and Laitin (2003) focus on

\footnotetext{
${ }^{7}$ Deraniyagala (2005) is a descriptive study without systematic empirical analysis at the district level. Murshed and Gates (2005) documents the differences in income across various caste categories, but does not investigate the impact of these social divisions on conflict intensity. The estimates in this study also suffer from multicollinearity, since the authors include schooling, life expectancy and the Human Development Index in the same regression.
} 
the conditions which specifically favor insurgency. Since insurgents are usually numerically weak compared to the governments they are fighting against, they must be able to hide from government forces and be able to garner local support for their activities. This suggests a number of testable hypotheses: first, the presence of mountainous or forested terrain, poorly served by roads, should increase insurgency. Second, insurgency should be more common in rural areas with low migration, where the rebels can easily punish people who do not support them. Third, the need to form a cohesive fighting force implies that insurgencies should be less common in areas of greater linguistic diversity and fewer means of communication.

Several cross-country studies have suggested that diverse societies are more prone to conflict (Easterly and Levine, 1997; Horowitz, 1985). Collier and Hoeffler (2004) also lay out a "grievance" framework, where the presence of different ethnic groups is likely to lead to the presence of significant animosity between groups; this is especially likely when one ethnic group tends to dominate over the others. Lee et al. (2004) find that the impact of democratization on human rights is limited by the presence of ethnic minorities. Several studies including Alesina, Baqir and Easterly (1999) and Miguel and Gugerty (2005) have also documented the inability of diverse societies to work together to obtain public goods.

Nepal has a very diverse society in several dimensions. Although the majority of the population is Hindu, there are deep caste divisions in the Nepalese society. Discrimination and human rights abuses against the lower castes are not uncommon (Human Rights Watch, 2004). Hence, in the Nepalese context, the grievance hypothesis suggests that areas with greater caste diversity or a greater dominance of high castes should have more conflict. Nepal also has considerable linguistic diversity, with only $60 \%$ of the population speaking Nepali. While other empirical analyses of the Nepal conflict (Bohara et al, 2006; Acharya, 2007) focus on the proportion of people who speak Nepali as a measure of social diversity, they do not construct polarization or fractionalization measures similar to the cross-country studies of civil war. ${ }^{8}$ These prior studies also do not examine the role of caste divisions at all.

\footnotetext{
${ }^{8}$ Duclos, Esteban and Ray (2004) discuss the concept, measurement and estimation of polarization in detail.
} 


\section{Data sources}

We conduct our analysis using district-level data. Nepal has 5 major regions and 75 districts. A district can be thought of as being comparable to a county in the US in the sense that it is administratively below the region level. The average area of a district was 1948 square kilometers in 2001, and the average population was 309,000. Our measures of conflict intensity are based on data provided in the annual Human Rights Yearbooks published by the Informal Sector Service Centre (INSEC), a Nepalese non-governmental organization. INSEC was able to provide us with data on the number of people killed both by the Maoists and by the state in this conflict, as well as measures of the number of people abducted by the Maoists and the number of people arrested by the state. It is difficult to construct a unique reliable measure of conflict intensity. Our main measure is the number of conflict-related deaths in the district normalized by the district population. We use population figures from the (pre-conflict) 1991 population census data for this purpose. We also check the robustness of our results to other measures of conflict intensity, such as a dummy which equals one if more than 100 people have been killed in the conflict so far. ${ }^{9}$ Another imperfect measure indicating the intensity of conflict is the number of people abducted by the Maoists normalized by the 1991 district population.

We construct our explanatory variables using data from the 1991 and 2001 population censuses, the Nepal Living Standards Measurement Survey 1995-1996, and the Nepal District Profiles based on official data. Details of data sources and variable construction are provided in the Data Appendix. As far as possible, these measures have been constructed using data collected before the violent conflict began in 1996. This helps to partially mitigate the concerns regarding backward causality, such as the possibility that the conflict itself has made some areas poorer or reduced the availability of public goods.

As suggested by the opportunity cost hypothesis, we construct district-level measures of poverty and literacy to proxy for the opportunity cost of recruiting rebel forces. We also have

\footnotetext{
${ }^{9}$ This is similar to the measures of civil war used in cross-country studies such as Fearon and Laitin (2003) and Miguel et al. (2004).
} 
measures of district-level infrastructure such as the number of post offices, schools, banks and health posts. Nepal has very few natural resources which can be easily expropriated (such as oil or diamonds); the only natural resource which the Maoists have expressed an interest in controlling is land. To capture geographic characteristics which make insurgency easier, we use the altitude (elevation) of the district to indicate the presence of hilly territory, as well as the proportion of district area which is forested. We construct a measure of the presence of roads as the total kilometers of road length, normalized by the area of the district. We also construct measures of government investment by looking at the change in the provision of roads and post offices in the 1990s.

To measure the extent of social divisions, we use information on the caste and language divisions in Nepalese society. We collected data on the number of people in different caste groups, as well as speaking different languages from the census of $2001 .^{10}$ We consider all castes which constitute more than $1 \%$ of the population. This gives us 76 categories, which we use to construct a diversity index. The index we use is the measure of polarization, proposed by Esteban and Ray (1994). Montalvo and Reynal-Querol (2005) find that ethnic polarization is highly correlated with the incidence of civil war in cross-country data. ${ }^{11}$ This index attains a maximum value of 1 , when the society is divided into two equal-sized groups, thus maximizing the chances of conflict. The index attains a minimum value of zero, either when the society is completely homogenous, or when every single person belongs to a different group. We also compute a measure of caste fractionalization, similar to the ethno-linguistic fractionalization measures used in several cross-country studies. This fractionalization measure captures the probability that two randomly selected persons would belong to different caste groups. We also use two alternative measures for the dominance of upper castes (Brahmins, Chhetris, Thakuris and Newars) in the district: one is simply the proportion of these castes in the population, and the second is a dummy which equals one if the proportion of these castes is between $45 \%$ and $90 \%$.

\footnotetext{
${ }^{10}$ We were unable to get this at the district level from the pre-conflict 1991 census; however, the nationwide proportions have changed very little between 1991 and 2001.

${ }^{11}$ See the Data Appendix for the details of the construction of the index.
} 
Around 120 different languages are spoken in Nepal, some by very small numbers of people. We construct a polarization index as well as a fractionalization index of linguistic diversity (similar to the ones computed for caste divisions), using all languages which are spoken by more than $1 \%$ of the population. Since the national language Nepali is the single most spoken language, it might be easier to easier to mobilize forces in Nepali-speaking areas. We thus include the proportion speaking Nepali as another measure of the ease of mobilization. We should note that caste polarization is highly correlated with the fraction of people who speak Nepali, since the high castes tend to be Nepali-speaking. On the other hand, caste polarization is negatively correlated with linguistic polarization, suggesting that these are two different dimensions of diversity.

Table 1 shows the mean of our variables. We note the large variation across districts both in the measures of conflict intensity, as well as in the potential explanatory variables. More than half of all districts have experienced 100 or more conflict-related deaths during 19962004, and one-third of all districts have experienced more than 150 deaths. There are also a large number of abductions by the Maoists, which probably reflects forced conscription into their ranks. We also note that, on average, $42 \%$ of the population was below the poverty line in Nepal at the time the conflict began.

Table 2 shows a correlation matrix between our measures of conflict and other variables. The different measures of conflict are correlated with each other to some extent (Panel A). Panel B shows that areas with higher literacy and lower poverty have less conflict; areas with more caste diversity have lower measures of conflict, and areas with a higher proportion of advantaged castes tend to have higher measures of conflict. Geographical characteristics also matter: the number of deaths due to the conflict is higher in areas at higher elevations or areas with more forest cover.

Panel C shows that the district poverty level is significantly correlated with other measures of under-development, such as infant mortality, the presence of roads and banks, as well as measures of the change in roads and post offices in the 1990s. Interestingly, poorer places also have higher measures of caste polarization. Panel D illustrates that the different measures of 
caste diversity are correlated with one another, but these are negatively correlated with measures of linguistic diversity, suggesting that these are different dimensions of social diversity. The next section uses regressions to investigate these correlations further.

\section{Empirical analysis of conflict}

We investigate the proximate correlates of the Maoist conflict in Nepal by running regressions of the following form:

$$
\text { Conflict }_{i}=a+b X_{i}+e_{i}
$$

in which Conflict ${ }_{i}$ is a measure of the intensity of conflict in district $i$, while $X_{i}$ is a vector of pre-conflict district-level characteristics. As mentioned above, our main measure of conflict intensity is the number of conflict-related deaths in the district from 1996 to 2004, normalized by the population of the district. All the specifications shown exclude the districts of Rolpa and Rukum, where the Maoist insurgency had its beginnings. This is because these districts have a very large number of deaths compared to other places (i.e. they are statistical outliers), and because they have other characteristics, including the long-standing presence of Communist activists, which probably helped to spark the Maoist movement. In this sense, our analysis focuses not on the onset, but on the spread of the conflict in the other regions of Nepal.

The robust associations with poverty that we report may not be causal relationships if there are other unmeasured factors which determine both pre-conflict poverty levels and the spread of the conflict later. Such variables could be other underlying population characteristics (e.g. propensity to use violence methods) or area characteristics not conducive to economic progress (e.g. disease burden).

Our estimates may also not be causal if districts that have experienced high conflict intensity are also districts that have been the theater of social unrest in the past. Past conflicts would then directly affect pre-insurgency levels of economic development. However, the fact 
that this type and intensity of conflict was unprecedented in Nepal's history gives us confidence that such a channel of influence is unlikely. This is also another reason to exclude the districts of Rolpa and Rukum, which did experience some political unrest before 1996.

\subsection{Main results}

Our main results are summarized in Table 3. Geographical factors such as elevation and the presence of forested area explain $25 \%$ of the variation in the intensity of conflict across districts (column (1)). ${ }^{12}$ Column (2) shows that the pre-conflict poverty level of the district is a significant predictor of the intensity of conflict. Columns (3)-(5) include measures of social divisions based on caste and language characteristics. After controlling for poverty, measures such as the prevalence of advantaged castes, caste or linguistic polarization do not significantly increase the intensity of conflict. The coefficient on poverty is always significant and fairly stable across specifications. To have an idea of the magnitude of these results, we note that a 10 percentage point increase in the district poverty rate is associated with an increase of 23-25 conflict-related deaths. ${ }^{13}$ Another way to gauge the magnitude is as follows: a one standard-deviation increase in poverty rate (23 percentage points) is associated with 54-57 additional conflict-related deaths (0.38-0.40 standard deviations).

Re-running these regressions with literacy rates instead of poverty (a measure of current as well as future earnings potential) yields results confirming that economic backwardness is associated with higher levels of conflict (columns (6) and (7)). Areas with higher literacy rates are less prone to conflict; however, now we also find caste polarization to be significantly correlated with the incidence of conflict, while the proportion of advantaged castes is marginally significant. An 11 percentage point (one standard deviation) increase in literacy rates is asso-

\footnotetext{
${ }^{12} \mathrm{We}$ also ran specifications including district rainfall and the square of the elevation; these variables are never significant.

${ }^{13}$ For instance, using the estimates in column (2), a 10 percentage point increase in poverty results in an additional 0.1005 deaths per 1000 population; average population of a district in 1991 was 246,548. Multiplying the two yields the figure of 25 additional deaths. The corresponding figures for the estimates in columns (3), (4) and (5) are 24, 24 and 23 respectively.
} 
ciated with an decrease of 65 conflict-related deaths, while a one standard-deviation increase in caste polarization is associated with an increase of 34 conflict-related deaths (column (6) estimates). Replacing poverty by a measure of infrastructure (road length per sq. km) also yields a similar result: presence of infrastructure is associated with lower conflict (columns (8) and (9)). It is interesting to note that elevation becomes insignificant when we include the road length variable, suggesting that part of the correlation with elevation arises because of the difficulty of building roads in hilly areas. ${ }^{14}$ We also show results with all these variables as regressors (though these are highly correlated with each other) in column (10).

Why do poorer areas witness a higher level of conflict-related deaths? There can be several potential reasons for this: first, consistent with the opportunity-cost view, the rebels find it easier to recruit people to their cause in poorer areas. Second, it could be the case that the government spends more resources to prevent activist activity in richer areas (through information-gathering and methods other than killing a lot of suspects), so that the number of deaths is lower in these areas. Alternatively, it could be that the state has a lower opportunity cost of violent repression in poorer areas. Third, for the same level of Maoist and state activity, poorer people are more likely to get killed since they have fewer means to protect themselves or to move away from the scene of the conflict (the "collateral damage" view).

We are at this stage unable to distinguish fully between these alternatives. Looking at the number of abductions by the Maoists (presumably to forcibly recruit people for their side), we find the evidence to be ambiguous: poverty is not significant in explaining the number of abductions, while literacy is (Table 5, columns (7) and (8)). Table 4 further shows that the district poverty level is significantly associated with deaths caused both by the Maoists and by the state. The magnitude of the impact is very similar: a one standard deviation increase in poverty (23 percentage points) is associated with a 0.36 standard deviation in both state-caused and Maoist-caused deaths (this works out to 38 additional state-caused deaths and 17 additional deaths caused by Maoists). This is consistent with Maoists having greater recruiting success in poorer areas, with the state exerting uniform effort to counter them in all areas; it is also consistent with the Maoists having uniform recruiting success in all

\footnotetext{
${ }^{14}$ Elevation and road length are significantly negatively correlated.
} 
areas, with the state using more resources in poorer areas. It is also interesting to note that caste polarization is not significant for Maoist-caused deaths, suggesting that Maoist success is probably not related to caste-based oppression.

\subsection{Robustness checks}

Appendix Table A1 runs the specification of Table 3, column (4), replacing the poverty measure with other measures of under-development and infrastructure availability: infant mortality rates, the number of schools, health posts, post offices and banks (all normalized by district population), as well as the change in the number of post offices and road length in the 1990's as a crude measure of government investment in these areas. Our results on poverty appear to be robust in the sense that only the measures which are significantly correlated with district poverty (infant mortality, number of banks, change in road length and change in number of post offices) appear to be significant predictors of conflict intensity. ${ }^{15}$

Appendix Table A2 checks the robustness of our results to different measures of caste and language divisions: caste and linguistic fractionalization measures, the proportion speaking Nepali and an advantaged caste dominance dummy (which equals 1 if the proportion of advantaged castes is between 45\% and 90\%). ${ }^{16,17}$ All these measures are statistically insignificant in predicting the intensity of conflict, except for the proportion speaking Nepali when we use the literacy rate as a measure of economic opportunities.

Appendix Table A3 adds additional control variables: the male-female literacy difference to capture gender differences in society (columns (1) and (2)), ${ }^{18}$ the average distance of the

\footnotetext{
${ }^{15}$ We also tried normalizing the number of schools, health posts, post offices and banks by the area of the district (rather than the population); in this case, all the infrastructure variables are highly significant predictors of the conflict. The results are available upon request.

${ }^{16}$ Most of the cross-country literature uses a similar measure of ethno-linguistic fractionalization to capture social diversity, though the polarization measure is preferred on theoretical and predictive grounds (Esteban and Ray (2004), Montalvo and Reynal-Querol (2005)).

${ }^{17}$ Collier and Hoeffler (2004) use a similar measure to capture the dominance of a specific group.

${ }^{18}$ There are several accounts of women being actively involved in the insurgency.
} 
district from Rolpa and Rukum where the conflict started (columns (3) and (4)), and the average distance of the district headquarters from the capital Kathmandu, which might be a proxy both for remoteness of the district, as well as the strength of the state (columns (5) and (6)). The results are also robust to dropping the four most urbanized districts from our sample (columns (7) and (8)). ${ }^{19}$

Columns (9) and (10) correct our estimates for potential spatial correlation of errors, since there might be spillover effects from one district to another. The results are very similar to those obtained without such correction. We also ran specifications controlling for region fixed effects (the coefficient on poverty becomes statistically insignificant, but literacy remains strongly significant), as well as adjusting the standard errors for region-level clustering (both poverty and literacy remain significant at the $10 \%$ level of significance) ${ }^{20}$

It is interesting that, in almost all our specifications, the relationship with caste polarization disappears when we control for poverty measures, but not when we include literacy. One possibility is that the effect of social divisions works through poverty i.e. all else being equal, an area with greater social divisions has greater poverty. This could be, for instance, because of economic opportunities being denied to people of lower castes in a more polarized society, or because the distribution of assets or incomes is also more unequal in a more polarized society (resulting in a few rich people and a lot of poor people). Regressing the poverty measure on the caste polarization measure (Appendix Table A4) reveals a positive relationship, even after controlling for geography and literacy rates, suggesting that part of the relationship of caste polarization with conflict can be explained by its impact on poverty.

\subsection{Onset versus intensity of conflict}

In this section, we separate out the impact of poverty and social diversity on the onset of conflict, and the intensity of conflict, once it has begun. Esteban and Ray (2007) suggest

\footnotetext{
${ }^{19}$ These districts are Kathmandu, Lalitpur, Bhaktapur and Kaski. We are unable to control directly for urbanization since this variable is missing for a large number of districts.

${ }^{20}$ These results are available upon request.
} 
that the relationship between polarization, fractionalization and conflict is likely to be highly non-linear; in particular, the relationship with the onset of conflict is likely to be different from the relationship with the intensity of conflict, once it has begun. Looking at Table 5, columns (1) and(2) show results from probit regressions where the dependent variable is a dummy for whether the district witnessed more than 100 conflict-related deaths. In addition to a robustness check on our conflict measure, this can also be interpreted as a measure of the onset of conflict in that district. Columns (3) and (4) show similar regressions for a dummy which equals one if the district had more than 150 conflict-related deaths. Columns (5) and (6) regress the log of the number of people killed on the log of total population as well as other covariates. In all cases, we find that poverty and literacy measures are strongly and significantly correlated with the incidence of conflict in the direction we expect. The coefficient on caste polarization is negative and significant for the more-than-100-deaths dummy, suggesting that very high levels of polarization in fact raise the costs of conflict.

Columns (7) and (8) use a completely different measure of the level of Maoist activity: the number of people abducted by the Maoists, normalized by the district population. Most of these abductions are likely to be for the purpose of forced conscription into the activist forces, and hence this variable can be interpreted as an indication of Maoist recruitment success. Here we find that the coefficient on poverty is positive but not significant, while the coefficient on literacy is significant; caste polarization is positive and significantly associated with the extent of abductions.

Columns (9)-(12) examine the impact of social and economic factors on the intensity of conflict, once it has started in a given region. We do this by running tobit regressions for the number of deaths per 1000 population, as well as the log number of deaths, provided these variables are above a certain threshold. ${ }^{21}$ We find that poorer areas are not just more likely to experience conflict: they also experience a higher intensity of conflict, once conflict has started. We find that the relationship between caste polarization and conflict is non-linear:

\footnotetext{
${ }^{21}$ The threshold for the number of deaths per 1000 population is 0.25 , which corresponds to the lowest quartile of its distribution. The threshold for the number of deaths is 100, which corresponds to the "onset" dummy in columns (1) and (2).
} 
polarization is negatively related to the incidence of conflict,but is not significantly associated with the intensity of the conflict, once it has started.

\subsection{Relationship between poverty and conflict over time}

Since we have annual data on conflict related deaths for 1999, 2002, 2003 and 2004, we can document the relationship between poverty and conflict intensity over time, and we find that this does not remain constant. Table 6 regresses year-wise conflict deaths on dummies for the bottom three quartiles of poverty (i.e. the omitted category is the top quartile or least poor people), as well as the top three quartiles of literacy (the omitted category is the least literate people). We find that poverty or literacy rates are not significantly associated with Maoistcaused deaths before 2002 (columns (1) and (2)), while they are significantly associated with state-caused deaths in 1999 itself (columns (9) and (10)). In 2002, when the conflict escalated, deaths caused by the Maoists and by the state are highest in the poorest quartile of districts (columns (3) and (11)); similarly, deaths caused by both sides are highest lower in the most literate districts, compared to the least literate. This might indicate a timeline in which the state was repressing Maoist activity more strongly in the poorest areas, which in turn could have led to greater support for the Maoist movement in those areas, resulting in a very high number of deaths in 2002, when the conflict intensified strongly.

In 2003, the intensity of conflict is not higher in poorer areas (though high literacy areas still show significantly lower conflict). It is interesting that by 2004, when the activists had captured a good deal of territory, we see that the districts in the second quartile of poverty show slightly higher levels of conflict (columns (7) and (15)). A similar result holds with literacy, where we see the second and third quartiles of literacy having higher levels of conflict. This does suggest that the Maoist and state effort in the conflict are moving away from the poorest areas to the not-so-poor ones. However, these differences are not statistically significant, and hence these results are indicative and not conclusive. This time path is consistent with the graphs in Figures 4A and 4B: as we see, the poorest districts have the highest casualties caused by both Maoists and the state in 2002, while in 2004 it is districts in the third quartile 
of poverty who have the highest number of deaths. This changing relationship with poverty further implies that what we observe is not just "collateral damage" i.e. poor people getting killed in conflict simply because they cannot protect themselves.

\section{Conclusion}

We conduct a within-country empirical analysis of the correlates of conflict intensity in Nepal, analogous to cross-country analyses of civil wars. Our within-country approach enables us to examine the spread of a single conflict across different parts of the country and over time. We find that conflict intensity is higher in places with greater poverty, and in places with geographical characteristics which favor insurgencies. The relationship of conflict intensity with measures of social diversity is much less robust: there is no significant association with measures of linguistic diversity, and part of the relationship with caste polarization appears to be because poverty is higher in more polarized areas, perhaps because social polarization limits the access to economic opportunities for members of the disadvantaged castes. Both deaths caused by the Maoists and those caused by the state are significantly higher in the poorest areas in the initial stages of the conflict. Over time, as Maoists gain control of the poorest areas, the highest intensity of conflict shifts from the poorest areas to somewhat better off places. The changing relationship with poverty suggests that we need to take into account the prior evolution of a conflict in broader analyses of conflict. The within-country analysis of conflict also raises some interesting questions: how do the parties in a conflict decide where to devote more resources to the conflict? Will the evolution of conflict always result in a steady state where one party wins outright? What are the circumstances under which conflict lasts for a long time? We hope to address these issues in future theoretical and empirical work. 


\section{References}

Acharya, Avidit (2007) 'The causes of insurgency in Nepal.' Working paper

Alesina, Alberto, Reza Baqir, and William Easterly (1999) 'Public goods and ethnic divisions.' Quarterly Journal of Economics 114(4), 1243-1284

Barron, Patrick, Kai Kaiser, and Menno Pradhan (2004) 'Local conflict in Indonesia: measuring incidence and identifying patterns.' mimeo, World Bank

Bohara, Alok, Neil Mitchell, and Mani Nepal (2006) 'Opportunity, democracy and the exchange of political violence: a subnational analysis of conflict in Nepal.' Journal of Conflict Resolution 50(1), 108-128

Bray, John, Leiv Lunde, and S. Mansoob Murshed (2003) 'Nepal: Economic drivers of the Maoist insurgency.' In The political economy of armed conflict: Beyond greed and grievance, ed. Karen Ballentine and Jake Sherman (Boulder, Colorado: Lynne Rienner Publishers)

Collier, Paul, and Anke Hoeffler (1998) 'On economic causes of civil war.' Oxford Economic Papers 50, 563-573

_ (2004) 'Greed and grievance in civil war.' Oxford Economic Papers (forthcoming) 56, 563595

Collier, Paul, and Nicholas Sambanis, eds (2005) Understanding Civil War: Evidence and Analysis (Washington DC: The World Bank)

Deininger, Klaus (2004) 'Causes and consequences of civil strife: micro-level evidence from Uganda.' mimeo, World Bank

Deraniyagala, Sonali (2005) 'The political economy of civil conflict in Nepal.' Oxford Development Studies 33(1), 47-62

Duclos, Jean-Yves, Joan Esteban, and Debraj Ray (2004) 'Polarization: Concepts, measurement, estimation.' Econometrica 72(6), 1737-1772 
Easterly, William, and Ross Levine (1997) 'Africa's growth tragedy: Policies and ethnic divisions.' Quarterly Journal of Economics 112(4), 1203-1250

Esteban, Joan, and Debraj Ray (2007) 'Polarization, fractionalization and conflict.' Journal of Peace Research, forthcoming

Esteban, Joan-Maria, and Debraj Ray (1994) 'On the measurement of polarization.' Econometrica 62(4), 819-851

Fearon, James (2005) 'Civil war since 1945: some facts and a theory.' Working paper

Fearon, James, and David Laitin (2003) 'Ethnicity, insurgency, and civil war.' American Political Science Review 97, 75-90

Gersony, Robert (2003) 'Sowing the wind: History and dynamics of the Maoist revolt in Nepal's Rapti hills.' Mercy Corps International Report

Human Rights Watch (2004) 'Discrimination against Dalits in Nepal.' http://hrw.org/english/docs/2004/02/09/nepal7322.htm

Humphreys, Macartan (2003) 'Economics and violent conflict.' Review essay, HPCR Conflict Prevention Initiative

_ (2005) 'Natural resources, conflict and conflict resolution.' Journal of Conflict Resolution $49(4), 508-537$

Informal Sector Service Centre (various issues) Human Rights Yearbook (Kathmandu, Nepal: INSEC)

Lee, Chris, Ronny Lindstrom, Will H. Moore, and Kursad Turan (2004) 'Ethnicity and repression: teh ethnic composition of countries and human rights violations.' In Understanding Human Rights Violations: New systematic studies, ed. S.C. Carey and S.C. Poe (Aldershot: Ashgate) pp. 186-201

Macours, Karen (2006) 'Relative deprivation and civil conflict in Nepal.' Working paper 
Miguel, Edward, and Mary Kay Gugerty (2005) 'Ethnic diversity, social sanctions and public goods in Kenya.' Journal of Public Economics 89(11-12), 2325-2368

Miguel, Edward, Shanker Satyanath, and Ernest Sergenti (2004) 'Economic shocks and civil conflict: an instrumental variables approach.' Journal of Political Economy 112(4), 725753

Montalvo, Jose G., and Marta Reynal-Querol (2005) 'Ethnic polarization, potential conflict and civil wars.' American Economic Review 95(3), 796-816

Murshed, Mansoob S., and Scott Gates (2005) 'Spatial-horizontal inequality and the Maoist insurgency in Nepal.' Review of Development Economics 9(1), 121-134

Raj, Prakash A. (2004) Maoists in the land of Buddha: an analytical study of the Maoist insurgency in Nepal (Delhi: Nirala Publications)

Sambanis, Nicholas (2001) 'Do ethnic and nonethnic civil wars have the same causes?' Journal of Conflict Resolution 45(3), 259-282

_ (2004) 'What is a civil war? Conceptual and empirical complexities of an operational definition.' Journal of Conflict Resolution 48(6), 814-858

Sengupta, Somini (2005) 'Where Maoists still matter.' The New York Times p. 30 October

Thapa, Deepak, and Bandira Sijapati (2004) A Kingdom Under Siege: Nepal's Maoist Insurgency, 1996 to 2003 (Kathmandu: The Printhouse) 


\section{Data Appendix}

A. Measures of conflict: These were computed using data obtained from the website of the Informal Sector Service Center (INSEC), a Nepalese NGO which documents human rights abuses across all the districts of Nepal. We obtained data on the number of conflict-related deaths between 13 February, 1996 and 31 December, 2004, caused by the state and by the Maoists separately. We also obtained annual data on the number of conflict-related deaths for the years 1999, 2002, 2003 and 2004 from the Human Rights Yearbook published by INSEC for various years. We use district population data from the 1991 census. The main variables are defined as follows:

Normalized total killed $=$ Total killed between 1996 and 2004 divided by district population (in thousands).

Dummy for more than 100 people killed equals one if the total people killed between 1996 and 2004 is greater than 100 .

Normalized total abducted $=$ Total number of people abducted by Maoists between 1996 and 2004 divided by district population (in thousands).

B. Geography: Data on latitude, rainfall and maximum elevation of the district was obtained from Nepal District Profile:1994. Data on proportion of district under forest area dates from March 2001 and was obtained from Japan Forest Technology Association (JAFTA), Information System Development Project For The Management of Tropical Forest: Activity Report of Wide Area Tropical Forest Resources Survey (Kingdom of Nepal).

C. Development indicators: Poverty figures (indicating the proportion of households in the districts below the poverty level) were obtained from the Nepal Living Standards Survey 1995-96 (NLSS-I) conducted by the World Bank. Literacy rates for 1991 were obtained from the 1991 Census. Infant mortality rates come from the Nepal District Profile:1994.

D. Infrastructure: Data on roads, post offices, schools, banks and health posts come from 
Nepal District Profile:1994 and Nepal District Profile : 2002. They are normalized by the population of the district.

E. Caste and language diversity : Caste polarization and fractionalization measures were computed using 2001 district level census data on population by caste (the 2001 nationwide caste proportions are very similar to the pre-conflict 1991 caste proportions; however, we do not have the latter at the district level). We retained castes which make up more than $1 \%$ of the district population, castes that make up less than $1 \%$ of the district population are classified as "others". We have 76 distinct categories under this measure. The proportion for each category is computed by dividing total number of individuals in the district falling under that category by respective district population. The polarization measures are constructed along the lines of Montalvo and Reynal-Querol (2005) as $4 \sum s_{i}^{2}\left(1-s_{i}\right)$, where $s_{i}$ is the proportion of (caste or linguistic) group $i$ in the population. The caste fractionalization measure is computed as $\sum s_{i}\left(1-s_{i}\right)=1-\sum s_{i}^{2}$, where $s_{i}$ is the proportion of caste group $i$ in the population. This represents the probability that two randomly drawn persons from the population belong to different caste groups.

Proportion of advantaged castes is computed as the proportion of district population belonging to the Brahmin, Chhetri, Thakuri or Newar castes. High caste dominance is a dummy which equals one if the proportion of advantaged castes is between 45 and 90 percent of the district population.

For measures of linguistic diversity, we use data from 2001 census on the number of people speaking different languages. We retain languages spoken by more than $1 \%$ of the population, and the remaining are put under "others" category. This gives us 13 different categories. Linguistic polarization and fractionalization measures are computed similar to the caste polarization and fractionalization measures. 
Table 1: Summary statistics

\begin{tabular}{|c|c|c|c|c|c|}
\hline & Observations & Mean & s.d. & Minimum & aximum \\
\hline Total number of deaths (Feb 1996-Dec 2004) & 75 & 150.33 & 143.69 & 0 & 810 \\
\hline Number killed by the state & 75 & 97.11 & 104.69 & 0 & 652 \\
\hline Number killed by the Maoists & 75 & 53.22 & 45.87 & 0 & 250 \\
\hline \multicolumn{6}{|l|}{ Year-by-year deaths } \\
\hline Total number of deaths 1999 & 75 & 11.79 & 15.26 & 0 & 91 \\
\hline Total number of deaths 2002 & 75 & 62.07 & 84.73 & 0 & 480 \\
\hline Total number of deaths 2003 & 75 & 24.84 & 19.49 & 0 & 108 \\
\hline Total number of deaths 2004 & 75 & 36.49 & 33.56 & 0 & 214 \\
\hline \multicolumn{6}{|l|}{ Measures of conflict intensity } \\
\hline Number of deaths per 1000 district population & 75 & 0.83 & 0.91 & 0.00 & 5.21 \\
\hline Number killed by state per 1000 population & 75 & 0.56 & 0.68 & 0.00 & 4.19 \\
\hline Number killed by Maoists per 1000 population & 75 & 0.27 & 0.26 & 0.00 & 1.28 \\
\hline Dummy for more than 100 killed & 75 & 0.56 & 0.50 & 0.00 & 1.00 \\
\hline Dummy for more than 150 killed & 75 & 0.33 & 0.47 & 0.00 & 1.00 \\
\hline Number of abductions per 1000 district population & 75 & 2.03 & 3.51 & 0.00 & 17.98 \\
\hline \multicolumn{6}{|l|}{ Geography } \\
\hline Maximum elevation ('000 meters) & 75 & 4.08 & 2.71 & 0.19 & 8.85 \\
\hline Proportion of forested area & 75 & 0.39 & 0.19 & 0.04 & 0.98 \\
\hline Rainfall ('000 ml) & 75 & 1.53 & 0.57 & 0.50 & 3.88 \\
\hline \multicolumn{6}{|l|}{ Development } \\
\hline Poverty Rate (proportion below poverty line) & 72 & 0.42 & 0.23 & 0.00 & 0.92 \\
\hline Infant Mortality Rate (deaths per 1000 births) & 75 & 93.85 & 32.00 & 32.00 & 201.00 \\
\hline Literacy 1991 (\%) & 75 & 38.03 & 11.02 & 19.60 & 70.10 \\
\hline Male-female literacy difference 1991 (\%) & 75 & 30.74 & 6.64 & -1.10 & 49.30 \\
\hline \multicolumn{6}{|l|}{ Infrastructure } \\
\hline Road length per sq km (1990) & 75 & 0.09 & 0.18 & 0.00 & 1.11 \\
\hline Post offices per 1000 population (1992) & 75 & 0.16 & 0.17 & 0.04 & 1.15 \\
\hline Schools per 1000 population (1994) & 75 & 1.35 & 0.76 & 0.44 & 4.85 \\
\hline Banks per 1000 population (1994) & 75 & 0.03 & 0.02 & 0.01 & 0.19 \\
\hline Health posts per 1000 population (1994) & 75 & 0.30 & 0.29 & 0.00 & 2.24 \\
\hline Change in road length (1990-1997) & 75 & 0.07 & 0.12 & -0.01 & 0.67 \\
\hline Change in number of post offices (1992-1999) & 75 & 31.89 & 25.48 & 2.47 & 141.68 \\
\hline \multicolumn{6}{|l|}{ Caste and language diversity } \\
\hline Caste Fractionalization & 75 & 0.79 & 0.10 & 0.41 & 0.93 \\
\hline Caste polarization & 75 & 0.53 & 0.14 & 0.24 & 0.78 \\
\hline Proportion of advantaged castes & 75 & 0.41 & 0.22 & 0.04 & 0.85 \\
\hline High Caste Dominance (dummy) & 75 & 0.40 & 0.49 & 0.00 & 1.00 \\
\hline Linguistic fractionalization & 75 & 0.42 & 0.24 & 0.01 & 0.79 \\
\hline Linguistic polarization & 75 & 0.59 & 0.28 & 0.03 & 0.93 \\
\hline Proportion speaking Nepali & 75 & 0.59 & 0.29 & 0.05 & 0.99 \\
\hline
\end{tabular}

All summary statistics are for district-level data.

See Data Appendix for sources and descriptions of all variables. 


\section{Table 2: Correlations}

Panel A: Correlations among conflict intensity measures

\begin{tabular}{|c|c|c|c|c|}
\hline & $\begin{array}{c}\text { Deaths per } \\
1000 \\
\text { population }\end{array}$ & $\begin{array}{c}\text { Killed by state } \\
\text { per } 1000 \\
\text { population }\end{array}$ & $\begin{array}{c}\text { Killed by Maoists } \\
\text { per } 1000 \\
\text { population }\end{array}$ & $\begin{array}{l}\text { Dummy for } \\
\text { more than } \\
100 \text { killed }\end{array}$ \\
\hline Killed by state per 1000 population & $0.9780 *$ & & & \\
\hline Killed by Maoists per 1000 population & $0.8901 *$ & $0.7754^{*}$ & & \\
\hline Dummy for more than 100 killed & $0.4700 *$ & $0.4525^{\star}$ & $0.4341^{*}$ & \\
\hline Abductions per 1000 population & $0.6438^{*}$ & $0.6717^{*}$ & $0.4812^{*}$ & $0.2584^{*}$ \\
\hline
\end{tabular}

Panel B: Correlations between conflict intensity and district characteristics

\begin{tabular}{lccc}
\hline & $\begin{array}{c}\text { Normalized } \\
\text { number of } \\
\text { deaths }\end{array}$ & $\begin{array}{c}\text { Dummy for } \\
\text { more than } 100 \\
\text { killed }\end{array}$ & $\begin{array}{c}\text { Normalized } \\
\text { number of } \\
\text { abductions }\end{array}$ \\
\hline Elevation & $0.3236^{*}$ & -0.0015 & 0.2016 \\
Proportion of forested area & $0.3562^{*}$ & $0.3635^{\star}$ & $0.2667^{\star}$ \\
Poverty Rate & $0.4939^{*}$ & $0.2370^{*}$ & $0.3597^{\star}$ \\
Total Literacy Rate 1991 & $-0.4285^{\star}$ & $-0.3370^{\star}$ & $-0.3029^{\star}$ \\
Road length per sq km 1990 & $-0.3208^{*}$ & $-0.2477^{*}$ & -0.2224 \\
Caste Fractionalization & $-0.2796^{*}$ & 0.1666 & $-0.3550^{\star}$ \\
Linguistic fractionalization & $-0.3922^{*}$ & -0.0943 & $-0.4217^{*}$ \\
Proportion of advantaged castes & $0.3691^{*}$ & -0.0274 & $0.4117^{\star}$ \\
Proportion speaking Nepali & $0.5173^{*}$ & 0.1313 & $0.4437^{\star}$ \\
\hline
\end{tabular}

Panel C: Correlations between district poverty rate and other district characteristics

\begin{tabular}{lc}
\hline & Poverty Rate \\
\hline Total Literacy Rate 1991 & $-0.5641^{\star}$ \\
Infant mortality rate & $0.6091^{\star}$ \\
Road length per sq km 1990 & $-0.3188^{\star}$ \\
Post offices per 1000 population (1992) & -0.0835 \\
Schools per 1000 population (1994) & -0.0499 \\
Banks per 1000 population (1994) & $-0.3519^{\star}$ \\
Health posts per 1000 population (1994) & -0.0229 \\
Change in road length (1990-1997) & $-0.3317^{\star}$ \\
Change in number of post offices (1992-1999) & $-0.3509^{\star}$ \\
Caste polarization & $0.3162^{\star}$ \\
Proportion of advantaged castes & $0.3572^{\star}$ \\
Proportion speaking Nepali & $0.4786^{\star}$ \\
\hline
\end{tabular}

Panel D: Correlations between caste polarization and other diversity measures

\begin{tabular}{lc}
\hline & Caste polarization \\
\hline Caste Fractionalization & $-0.8376^{*}$ \\
Proportion of advantaged castes & $0.6952^{*}$ \\
High caste dominance dummy & $0.5302^{*}$ \\
Linguistic fractionalization & $-0.3790^{\star}$ \\
Linguistic polarization & $-0.2526^{*}$ \\
Proportion speaking Nepali & $0.6386^{*}$ \\
\hline
\end{tabular}

See Data Appendix for sources and descriptions of variables. All correlations are computed excluding the districts of Rolpa and Rukum. * indicates a significant correlation at the $5 \%$ level of significance. 


\section{Table 3 : Correlates of conflict-related deaths}

\begin{tabular}{|c|c|c|c|c|c|c|c|c|c|c|}
\hline & \multicolumn{10}{|c|}{ Dependent variable $=$ Conflict-related deaths per 1000 population } \\
\hline & (1) & (2) & (3) & (4) & (5) & (6) & (7) & (8) & (9) & (10) \\
\hline Elevation & $\begin{array}{c}0.086^{\star \star \star} \\
(0.022)\end{array}$ & $\begin{array}{c}0.072^{\star * *} \\
(0.020)\end{array}$ & $\begin{array}{c}0.067^{* * *} \\
(0.023)\end{array}$ & $\begin{array}{c}0.063^{* \star *} \\
(0.022)\end{array}$ & $\begin{array}{c}0.071^{\star * \star} \\
(0.020)\end{array}$ & $\begin{array}{c}0.062^{\star * *} \\
(0.023)\end{array}$ & $\begin{array}{l}0.057^{\star \star} \\
(0.021)\end{array}$ & $\begin{array}{c}0.041 \\
(0.028)\end{array}$ & $\begin{array}{c}0.035 \\
(0.025)\end{array}$ & $\begin{array}{l}0.061^{\star *} \\
(0.029)\end{array}$ \\
\hline Proportion of forested area & $\begin{array}{c}1.372^{\star * *} \\
(0.330)\end{array}$ & $\begin{array}{c}1.074^{\star \star \star} \\
(0.287)\end{array}$ & $\begin{array}{l}1.040 * * * \\
(0.300)\end{array}$ & $\begin{array}{c}0.993^{* * *} \\
(0.308)\end{array}$ & $\begin{array}{l}1.049 * * * \\
(0.309)\end{array}$ & $\begin{array}{c}0.948 * \star * \\
(0.327)\end{array}$ & $\begin{array}{c}0.981^{\star * *} \\
(0.324)\end{array}$ & $\begin{array}{l}0.829 * \star \\
(0.394)\end{array}$ & $\begin{array}{l}0.881^{\star \star} \\
(0.406)\end{array}$ & $\begin{array}{l}1.033^{\star \star} \\
(0.394)\end{array}$ \\
\hline Poverty rate $1995-96$ & & $\begin{array}{c}1.005^{\star \star \star} \\
(0.328)\end{array}$ & $\begin{array}{c}0.966^{\star \star *} \\
(0.293)\end{array}$ & $\begin{array}{c}0.967^{\star \star \star} \\
(0.308)\end{array}$ & $\begin{array}{c}0.954^{\star * *} \\
(0.299)\end{array}$ & & & & & $\begin{array}{c}0.444 \\
(0.364)\end{array}$ \\
\hline Literacy rate 1991 & & & & & & $\begin{array}{c}-0.024^{\star \star \star} \\
(0.006)\end{array}$ & $\begin{array}{c}-0.023^{\star \star \star} \\
(0.006)\end{array}$ & & & $\begin{array}{c}-0.019 * * \\
(0.008)\end{array}$ \\
\hline Road length per sq km & & & & & & & & $\begin{array}{c}-0.939 \star * \\
(0.365)\end{array}$ & $\begin{array}{c}-0.783^{\star \star} \\
(0.295)\end{array}$ & $\begin{array}{c}0.010 \\
(0.287)\end{array}$ \\
\hline Proportion of advantaged castes & & & $\begin{array}{c}0.161 \\
(0.341)\end{array}$ & & & $\begin{array}{c}0.747^{*} \\
(0.388)\end{array}$ & & $\begin{array}{c}0.893^{\star} \\
(0.487)\end{array}$ & & $\begin{array}{c}0.431 \\
(0.614)\end{array}$ \\
\hline Caste polarization & & & & $\begin{array}{c}0.378 \\
(0.399)\end{array}$ & & & $\begin{array}{l}0.996 \star \star \\
(0.470)\end{array}$ & & $\begin{array}{l}1.266^{\star \star} \\
(0.604)\end{array}$ & $\begin{array}{c}0.284 \\
(0.596)\end{array}$ \\
\hline Linguistic polarization & & & & & $\begin{array}{l}-0.083 \\
(0.302)\end{array}$ & & & & & $\begin{array}{c}0.149 \\
(0.266)\end{array}$ \\
\hline Observations & 73 & 70 & 70 & 70 & 70 & 73 & 73 & 73 & 73 & 70 \\
\hline R-squared & 0.25 & 0.40 & 0.41 & 0.41 & 0.40 & 0.44 & 0.42 & 0.33 & 0.31 & 0.46 \\
\hline
\end{tabular}

Robust standard errors in parentheses

* significant at 10\%; ** significant at 5\%; *** significant at $1 \%$

Regressions are based on district level data.

All regressions exclude the districts of Rolpa and Rukum.

See Data Appendix for sources and descriptions of all variables. 
Table 4 : Correlates of deaths caused by Maoists and the state

\begin{tabular}{|c|c|c|c|c|c|c|c|c|c|c|}
\hline & \multicolumn{5}{|c|}{$\begin{array}{c}\text { Dependent variable }= \\
\text { Deaths caused by Maoists per } 1000 \text { population }\end{array}$} & \multicolumn{5}{|c|}{$\begin{array}{c}\text { Dependent variable }= \\
\text { Death caused by the state per } 1000 \text { population }\end{array}$} \\
\hline & $(1)$ & $(2)$ & (3) & $(4)$ & $(5)$ & $(6)$ & $(7)$ & $(8)$ & $(9)$ & $(10)$ \\
\hline Elevation & $\begin{array}{l}0.027^{* * *} \\
(0.008)\end{array}$ & $\begin{array}{l}0.021^{* * *} \\
(0.007)\end{array}$ & $\begin{array}{l}0.022^{* * *} \\
(0.007)\end{array}$ & $\begin{array}{l}0.019 * * * \\
(0.007)\end{array}$ & $\begin{array}{l}0.020^{* * *} \\
(0.007)\end{array}$ & $\begin{array}{l}0.059 * * * \\
(0.016)\end{array}$ & $\begin{array}{l}0.046 * \star \\
(0.018)\end{array}$ & $\begin{array}{l}0.042^{\star *} \\
(0.017)\end{array}$ & $\begin{array}{l}0.043^{\star *} \\
(0.018)\end{array}$ & $\begin{array}{l}0.037^{* *} \\
(0.016)\end{array}$ \\
\hline Proportion of forested area & $\begin{array}{l}0.371^{* * *} \\
(0.140)\end{array}$ & $\begin{array}{l}0.310^{* * *} \\
(0.114)\end{array}$ & $\begin{array}{l}0.312^{* * *} \\
(0.114)\end{array}$ & $\begin{array}{c}0.237 \\
(0.143)\end{array}$ & $\begin{array}{l}0.264^{\star} \\
(0.147)\end{array}$ & $\begin{array}{c}1.001^{\star * *} \\
(0.214)\end{array}$ & $\begin{array}{c}0.729 * * * \\
(0.208)\end{array}$ & $\begin{array}{c}0.682^{\star * *} \\
(0.218)\end{array}$ & $\begin{array}{c}0.712^{* * *} \\
(0.208)\end{array}$ & $\begin{array}{c}0.717^{\star * *} \\
(0.204)\end{array}$ \\
\hline Poverty rate $1995-96$ & & $\begin{array}{c}0.294^{\star \star *} \\
(0.096)\end{array}$ & $\begin{array}{c}0.299 * * * \\
(0.102)\end{array}$ & & & & $\begin{array}{c}0.671^{\star \star *} \\
(0.223)\end{array}$ & $\begin{array}{c}0.668^{\star \star \star} \\
(0.229)\end{array}$ & & \\
\hline Literacy rate 1991 & & & & $\begin{array}{c}-0.008^{\star \star *} \\
(0.002)\end{array}$ & $\begin{array}{c}-0.007^{\star \star *} \\
(0.002)\end{array}$ & & & & $\begin{array}{c}-0.017^{\star \star \star} \\
(0.004)\end{array}$ & $\begin{array}{c}-0.016 * \star \star \\
(0.004)\end{array}$ \\
\hline Proportion of advantaged castes & & $\begin{array}{c}0.027 \\
(0.101)\end{array}$ & & $\begin{array}{c}0.23{ }^{*} \\
(0.129)\end{array}$ & & & $\begin{array}{c}0.134 \\
(0.257)\end{array}$ & & $\begin{array}{c}0.507^{*} \\
(0.281)\end{array}$ & \\
\hline Caste polarization & & & $\begin{array}{c}0.020 \\
(0.139)\end{array}$ & & $\begin{array}{c}0.245 \\
(0.186)\end{array}$ & & & $\begin{array}{c}0.357 \\
(0.286)\end{array}$ & & $\begin{array}{l}0.751 * * \\
(0.321)\end{array}$ \\
\hline Observations & 73 & 70 & 70 & 73 & 73 & 73 & 70 & 70 & 73 & 73 \\
\hline R-squared & 0.20 & 0.38 & 0.37 & 0.37 & 0.34 & 0.25 & 0.37 & 0.37 & 0.42 & 0.41 \\
\hline
\end{tabular}

Robust standard errors in parentheses

* significant at 10\%; ** significant at 5\%; *** significant at $1 \%$

Regressions are based on district level data.

All regressions exclude the districts of Rolpa and Rukum.

See Data Appendix for sources and descriptions of all variables. 


\section{Table 5: Onset and continuation of conflict}

\begin{tabular}{|c|c|c|c|c|c|c|c|c|c|c|c|c|}
\hline \multirow{3}{*}{$\begin{array}{l}\text { Estimation } \\
\text { Dependent variable }\end{array}$} & \multirow{2}{*}{\multicolumn{2}{|c|}{$\begin{array}{c}\text { Probit } \\
\text { Dummy for more } \\
\text { than } 100 \text { deaths }\end{array}$}} & \multirow{2}{*}{\multicolumn{2}{|c|}{$\begin{array}{c}\text { Probit } \\
\text { Dummy for more } \\
\text { than } 150 \text { deaths }\end{array}$}} & \multicolumn{2}{|c|}{ OLS } & \multicolumn{2}{|c|}{ OLS } & \multicolumn{4}{|c|}{ Tobit } \\
\hline & & & & & \multicolumn{2}{|c|}{ Log(\#deaths) } & \multicolumn{2}{|c|}{$\begin{array}{l}\text { Abductions per } \\
1000 \text { population }\end{array}$} & \multicolumn{2}{|c|}{$\begin{array}{c}\text { \#deaths per } 1000 \\
\text { population }\end{array}$} & \multicolumn{2}{|c|}{ Log(\#deaths) } \\
\hline & (1) & (2) & (3) & (4) & $(5)$ & (6) & $(7)$ & (8) & (9) & $(10)$ & $(11)$ & (12) \\
\hline \multirow[t]{2}{*}{ Elevation } & $0.126^{*}$ & $0.140 * *$ & 0.101 & 0.116 & $0.107^{\star \star *}$ & $0.125^{\star \star \star}$ & 0.145 & 0.098 & $0.095^{\star * \star}$ & $0.098^{\star \star *}$ & 0.056 & $0.089 * \star$ \\
\hline & $(0.069)$ & $(0.068)$ & $(0.081)$ & $(0.085)$ & $(0.034)$ & $(0.033)$ & $(0.149)$ & $(0.137)$ & $(0.031)$ & $(0.031)$ & $(0.036)$ & $(0.036)$ \\
\hline \multirow[t]{2}{*}{ Proportion of forested area } & $3.628 * * *$ & $4.221^{* * *}$ & $4.568^{\star * \star}$ & $5.110 * \star \star$ & $2.058^{\star \star *}$ & $1.968 * \star \star$ & 2.157 & 3.220 & $1.514^{\star \star \star}$ & $1.595^{\star \star \star}$ & $1.761^{\star \star \star}$ & $1.961^{\star \star \star}$ \\
\hline & $(1.224)$ & $(1.345)$ & $(1.248)$ & $(1.377)$ & $(0.448)$ & $(0.416)$ & $(2.328)$ & $(2.010)$ & $(0.465)$ & $(0.436)$ & $(0.486)$ & $(0.472)$ \\
\hline \multirow[t]{2}{*}{ Poverty rate 1995-96 } & $1.506^{\star \star}$ & & $1.737^{\star \star}$ & & $1.030 * * *$ & & 3.700 & & $0.950 * * *$ & & $0.841^{\star *}$ & \\
\hline & $(0.717)$ & & $(0.865)$ & & $(0.350)$ & & $(2.275)$ & & $(0.335)$ & & $(0.355)$ & \\
\hline Literacy rate 1991 & & $\begin{array}{l}-0.049 * \star \star \\
(0.016)\end{array}$ & & $\begin{array}{l}-0.049 * * * \\
(0.017)\end{array}$ & & $\begin{array}{l}-0.032^{\star \star *} \\
(0.006)\end{array}$ & & $\begin{array}{l}-0.089 * * \\
(0.037)\end{array}$ & & $\begin{array}{l}-0.031^{* * *} \\
(0.007)\end{array}$ & & $\begin{array}{l}-0.031^{\star \star \star} \\
(0.008)\end{array}$ \\
\hline \multirow[t]{2}{*}{ Caste polarization } & $-4.130 \star \star$ & $-4.171^{* \star}$ & -0.409 & -0.448 & -0.253 & 0.992 & $6.057^{\star \star}$ & $7.004^{\star \star}$ & 0.562 & 1.044 & -0.756 & -0.145 \\
\hline & $(1.776)$ & $(1.904)$ & $(1.801)$ & $(1.737)$ & $(0.783)$ & $(0.733)$ & $(2.874)$ & (3.114) & $(0.700)$ & $(0.661)$ & $(0.775)$ & $(0.762)$ \\
\hline \multirow[t]{2}{*}{ Log (population) } & & & & & $0.752^{\star \star \star}$ & $1.021^{\star \star \star}$ & & & & & 0.244 & $0.465^{\star \star}$ \\
\hline & & & & & $(0.207)$ & $(0.175)$ & & & & & $(0.187)$ & $(0.182)$ \\
\hline Observations & 70 & 73 & 70 & 73 & 70 & 73 & 70 & 73 & 70 & 73 & 70 & 73 \\
\hline R-squared & & & & & 0.57 & 0.68 & 0.23 & 0.24 & & & & \\
\hline
\end{tabular}

Robust standard errors in parentheses

* significant at 10\%; ** significant at 5\%; *** significant at $1 \%$

All regressions exclude the districts of Rolpa and Rukum.

See Data Appendix for sources and descriptions of all variables.

Columns (1)-(4) report results from probit regressions. Columns (5)-(8) report OLS regressions.

Columns (9)-(10) report tobit regressions, with cutoff of greater than 0.25 deaths per 1000 population.

Columns (11)-(12) report tobit regressions, with cutoff of greater than 100 deaths. 
Table 6 : Relationship of conflict intensity and poverty over time

\begin{tabular}{|c|c|c|c|c|c|c|c|c|c|c|c|c|c|c|c|c|}
\hline & \multicolumn{8}{|c|}{ Dependent variable: Maoist-caused deaths per 1000 population } & \multicolumn{8}{|c|}{ Dependent variable: state-caused deaths per 1000 population } \\
\hline & \multicolumn{2}{|c|}{$\underline{1999}$} & \multicolumn{2}{|c|}{$\underline{2002}$} & \multicolumn{2}{|c|}{$\underline{2003}$} & \multicolumn{2}{|c|}{$\underline{2004}$} & \multicolumn{2}{|c|}{$\underline{1999}$} & \multicolumn{2}{|c|}{$\underline{2002}$} & \multicolumn{2}{|c|}{$\underline{2003}$} & \multicolumn{2}{|c|}{$\underline{2004}$} \\
\hline & $(1)$ & $(2)$ & (3) & (4) & $(5)$ & $(6)$ & $(7)$ & $(8)$ & $(9)$ & $(10)$ & $(11)$ & $(12)$ & $(13)$ & $(14)$ & $(15)$ & $(16)$ \\
\hline Elevation & $\begin{array}{c}0.001 \\
(0.001)\end{array}$ & $\begin{array}{c}0.001 \\
(0.001)\end{array}$ & $\begin{array}{c}0.003 \\
(0.004)\end{array}$ & $\begin{array}{c}0.003 \\
(0.004)\end{array}$ & $\begin{array}{c}0.001 \\
(0.001)\end{array}$ & $\begin{array}{c}0.001 \\
(0.001)\end{array}$ & $\begin{array}{c}0.003 \\
(0.004)\end{array}$ & $\begin{array}{c}0.002 \\
(0.003)\end{array}$ & $\begin{array}{c}0.001 \\
(0.001)\end{array}$ & $\begin{array}{c}0.001 \\
(0.001)\end{array}$ & $\begin{array}{c}0.011 \\
(0.009)\end{array}$ & $\begin{array}{c}0.012 \\
(0.009)\end{array}$ & $\begin{array}{l}0.007^{*} \\
(0.004)\end{array}$ & $\begin{array}{c}0.006^{*} \\
(0.004)\end{array}$ & $\begin{array}{l}0.024^{* *} \\
(0.012)\end{array}$ & $\begin{array}{l}0.021 * \\
(0.011)\end{array}$ \\
\hline Prop. forested area & $\begin{array}{l}0.037^{*} \\
(0.019)\end{array}$ & $\begin{array}{c}0.019 \\
(0.034)\end{array}$ & $\begin{array}{c}0.084 \\
(0.065)\end{array}$ & $\begin{array}{l}0.152^{*} \\
(0.078)\end{array}$ & $\begin{array}{c}0.025 \\
(0.024)\end{array}$ & $\begin{array}{c}0.028 \\
(0.023)\end{array}$ & $\begin{array}{c}0.045 \\
(0.037)\end{array}$ & $\begin{array}{c}0.034 \\
(0.038)\end{array}$ & $\begin{array}{l}0.054 * * \\
(0.025)\end{array}$ & $\begin{array}{l}0.060^{*} \\
(0.032)\end{array}$ & $\begin{array}{l}0.380^{* *} \\
(0.154)\end{array}$ & $\begin{array}{c}0.504 * * * \\
(0.163)\end{array}$ & $\begin{array}{c}0.086 * * \\
(0.042)\end{array}$ & $\begin{array}{c}0.100 * * \\
(0.043)\end{array}$ & $\begin{array}{c}0.029 \\
(0.096)\end{array}$ & $\begin{array}{c}0.051 \\
(0.083)\end{array}$ \\
\hline Poorest quartile & $\begin{array}{c}0.004 \\
(0.009)\end{array}$ & & $\begin{array}{c}0.116^{* *} \\
(0.048)\end{array}$ & & $\begin{array}{c}0.006 \\
(0.010)\end{array}$ & & $\begin{array}{l}-0.022 \\
(0.023)\end{array}$ & & $\begin{array}{c}0.024 * * \\
(0.012)\end{array}$ & & $\begin{array}{l}0.235^{* *} \\
(0.106)\end{array}$ & & $\begin{array}{c}0.023 \\
(0.027)\end{array}$ & & $\begin{array}{l}-0.037 \\
(0.047)\end{array}$ & \\
\hline Second-poorest quartile & $\begin{array}{c}0.003 \\
(0.004)\end{array}$ & & $\begin{array}{c}0.016 \\
(0.018)\end{array}$ & & $\begin{array}{c}0.008 \\
(0.009)\end{array}$ & & $\begin{array}{c}0.023 \\
(0.026)\end{array}$ & & $\begin{array}{l}-0.001 \\
(0.003)\end{array}$ & & $\begin{array}{c}0.047 \\
(0.056)\end{array}$ & & $\begin{array}{l}-0.011 \\
(0.023)\end{array}$ & & $\begin{array}{c}0.066 \\
(0.099)\end{array}$ & \\
\hline Third-poorest quartile & $\begin{array}{l}-0.010^{*} \\
(0.005)\end{array}$ & & $\begin{array}{c}0.010 \\
(0.015)\end{array}$ & & $\begin{array}{c}0.003 \\
(0.007)\end{array}$ & & $\begin{array}{c}0.007 \\
(0.016)\end{array}$ & & $\begin{array}{c}-0.002 \\
(0.005)\end{array}$ & & $\begin{array}{l}-0.017 \\
(0.050)\end{array}$ & & $\begin{array}{l}-0.015 \\
(0.021)\end{array}$ & & $\begin{array}{l}-0.002 \\
(0.029)\end{array}$ & \\
\hline Highest literacy quartile & & $\begin{array}{l}-0.014 \\
(0.012)\end{array}$ & & $\begin{array}{c}-0.113^{* *} \\
(0.044)\end{array}$ & & $\begin{array}{c}-0.018 * * * \\
(0.007)\end{array}$ & & $\begin{array}{c}-0.003 \\
(0.012)\end{array}$ & & $\begin{array}{l}-0.020^{*} \\
(0.011)\end{array}$ & & $\begin{array}{c}-0.267 * * * \\
(0.089)\end{array}$ & & $\begin{array}{c}-0.045^{* *} \\
(0.019)\end{array}$ & & $\begin{array}{l}-0.008 \\
(0.022)\end{array}$ \\
\hline 2nd highest literacy quartile & & $\begin{array}{l}-0.010 \\
(0.012)\end{array}$ & & $\begin{array}{c}-0.073 \\
(0.047)\end{array}$ & & $\begin{array}{l}-0.009 \\
(0.008)\end{array}$ & & $\begin{array}{c}0.035 \\
(0.025)\end{array}$ & & $\begin{array}{l}-0.017 \\
(0.012)\end{array}$ & & $\begin{array}{c}-0.181^{*} \\
(0.096)\end{array}$ & & $\begin{array}{c}-0.023 \\
(0.022)\end{array}$ & & $\begin{array}{c}0.103 \\
(0.090)\end{array}$ \\
\hline 3rd highest literacy quartile & & $\begin{array}{c}-0.014 \\
(0.011)\end{array}$ & & $\begin{array}{l}-0.080 \\
(0.052)\end{array}$ & & $\begin{array}{c}0.002 \\
(0.008)\end{array}$ & & $\begin{array}{c}0.017 \\
(0.017)\end{array}$ & & $\begin{array}{l}-0.018 \\
(0.015)\end{array}$ & & $\begin{array}{c}-0.271^{* * *} \\
(0.093)\end{array}$ & & $\begin{array}{c}-0.009 \\
(0.025)\end{array}$ & & $\begin{array}{c}0.032 \\
(0.029)\end{array}$ \\
\hline Caste Polarization & $\begin{array}{l}-0.010 \\
(0.023)\end{array}$ & $\begin{array}{c}0.014 \\
(0.031)\end{array}$ & $\begin{array}{c}0.061 \\
(0.082)\end{array}$ & $\begin{array}{c}0.155 \\
(0.094)\end{array}$ & $\begin{array}{c}0.004 \\
(0.027)\end{array}$ & $\begin{array}{c}0.000 \\
(0.020)\end{array}$ & $\begin{array}{c}0.030 \\
(0.068)\end{array}$ & $\begin{array}{l}-0.019 \\
(0.049)\end{array}$ & $\begin{array}{l}-0.038 \\
(0.029)\end{array}$ & $\begin{array}{c}-0.004 \\
(0.020)\end{array}$ & $\begin{array}{c}0.241 \\
(0.206)\end{array}$ & $\begin{array}{c}0.473^{* *} \\
(0.216)\end{array}$ & $\begin{array}{l}-0.042 \\
(0.070)\end{array}$ & $\begin{array}{c}0.010 \\
(0.059)\end{array}$ & $\begin{array}{c}0.077 \\
(0.186)\end{array}$ & $\begin{array}{l}-0.066 \\
(0.087)\end{array}$ \\
\hline Observations & 70 & 73 & 70 & 73 & 70 & 73 & 70 & 73 & 70 & 73 & 70 & 73 & 70 & 73 & 70 & 73 \\
\hline R-squared & 0.15 & 0.07 & 0.23 & 0.23 & 0.08 & 0.18 & 0.08 & 0.08 & 0.23 & 0.19 & 0.33 & 0.37 & 0.16 & 0.19 & 0.12 & 0.12 \\
\hline
\end{tabular}

\section{Robust standard errors in parentheses}

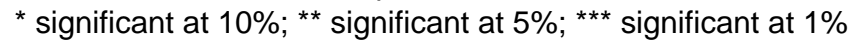

Regressions are based on district level data.

All regressions exclude the districts of Rolpa and Rukum.

See Data Appendix for sources and descriptions of all variables.

Poorest quartile of poverty has poverty $>0.62$; second-poorest has $0.38<$ poverty $<0.58$; third quartile has $0.26<$ poverty $<0.38$ and richest quartile has poverty $<0.26$.

Highest literacy quartile has literacy $>46 \%$; 2nd highest literacy quartile has 39\%<literacy<46\%; 3rd highest quartile has 30\%<literacy<39\% and

lowest quartile (omitted category) has literacy<30\%. 
Appendix Table A1 : Robustness using different measures of underdevelopment and infrastructure

\begin{tabular}{|c|c|c|c|c|c|c|c|}
\hline & \multicolumn{7}{|c|}{ Dependent variable = Deaths per 1000 population } \\
\hline & $(1)$ & $(2)$ & $(3)$ & $(4)$ & (5) & $(6)$ & $(7)$ \\
\hline Elevation & $\begin{array}{l}0.052^{* *} \\
(0.023)\end{array}$ & $\begin{array}{c}0.084^{\star * \star} \\
(0.031)\end{array}$ & $\begin{array}{l}0.064^{\star *} \\
(0.025)\end{array}$ & $\begin{array}{c}0.075^{\star \star \star} \\
(0.025)\end{array}$ & $\begin{array}{c}0.068^{\star \star \star} \\
(0.023)\end{array}$ & $\begin{array}{c}0.038 \\
(0.025)\end{array}$ & $\begin{array}{c}0.032 \\
(0.024)\end{array}$ \\
\hline Proportion of forested area & $\begin{array}{l}0.823^{\star *} \\
(0.361)\end{array}$ & $\begin{array}{c}1.044^{\star \star \star} \\
(0.345)\end{array}$ & $\begin{array}{c}1.152^{\star \star \star} \\
(0.343)\end{array}$ & $\begin{array}{c}1.001^{\star * *} \\
(0.377)\end{array}$ & $\begin{array}{l}0.835^{\star *} \\
(0.364)\end{array}$ & $\begin{array}{l}0.978 * \star \\
(0.372)\end{array}$ & $\begin{array}{l}0.869 * * \\
(0.401)\end{array}$ \\
\hline Infant mortality rate & $\begin{array}{c}0.008 * \star \star \\
(0.003)\end{array}$ & & & & & & \\
\hline Schools per 1000 population (1994) & & $\begin{array}{c}-0.139 \\
(0.122)\end{array}$ & & & & & \\
\hline Health posts per 1000 population (1994) & & & $\begin{array}{c}-0.028 \\
(0.297)\end{array}$ & & & & \\
\hline Post offices per 1000 population (1992) & & & & $\begin{array}{l}-0.510 \\
(0.345)\end{array}$ & & & \\
\hline Banks per 1000 population (1994) & & & & & $\begin{array}{c}-7.379 \star \star \star \\
(2.560)\end{array}$ & & \\
\hline Change in road length (1990-1997) & & & & & & $\begin{array}{c}-1.232^{\star \star \star} \\
(0.374)\end{array}$ & \\
\hline Change in number of post offices (1992-1999) & & & & & & & $\begin{array}{c}-0.007^{* \star *} \\
(0.002)\end{array}$ \\
\hline Caste polarization & $\begin{array}{c}0.292 \\
(0.422)\end{array}$ & $\begin{array}{c}1.112^{*} \\
(0.590)\end{array}$ & $\begin{array}{c}0.909 * \\
(0.528)\end{array}$ & $\begin{array}{l}1.060^{*} \\
(0.572)\end{array}$ & $\begin{array}{l}1.098 * \star \\
(0.546)\end{array}$ & $\begin{array}{l}1.159 * * \\
(0.558)\end{array}$ & $\begin{array}{l}1.113^{\star *} \\
(0.547)\end{array}$ \\
\hline Observations & 73 & 73 & 73 & 73 & 73 & 73 & 73 \\
\hline R-squared & 0.37 & 0.29 & 0.28 & 0.29 & 0.33 & 0.32 & 0.34 \\
\hline
\end{tabular}

Robust standard errors in parentheses

* significant at $10 \%$; ** significant at $5 \%$; *** significant at $1 \%$

Regressions are based on district level data, excluding the districts of Rolpa and Rukum.

See Data Appendix for sources and descriptions of all variables. 
Appendix Table A2 : Robustness using different measures of caste and language divisions

\begin{tabular}{|c|c|c|c|c|c|c|c|c|c|}
\hline & \multicolumn{9}{|c|}{ Dependent variable = Deaths per 1000 population } \\
\hline & $(1)$ & $(2)$ & $(3)$ & $(4)$ & $(5)$ & (6) & $(7)$ & $(8)$ & $(9)$ \\
\hline Elevation & $\begin{array}{c}0.069 * \star \star \\
(0.024)\end{array}$ & $\begin{array}{c}0.069 * \star * \\
(0.021)\end{array}$ & $\begin{array}{c}0.069 * * * \\
(0.020)\end{array}$ & $\begin{array}{l}0.057^{\star *} \\
(0.023)\end{array}$ & $\begin{array}{c}0.074^{\star \star \star} \\
(0.024)\end{array}$ & $\begin{array}{c}0.073^{\star * *} \\
(0.022)\end{array}$ & $\begin{array}{c}0.079 \star \star \star \\
(0.021)\end{array}$ & $\begin{array}{l}0.047 * \star \\
(0.022)\end{array}$ & $\begin{array}{c}0.080 * * \star \\
(0.021)\end{array}$ \\
\hline Proportion of forested area & $\begin{array}{c}1.070 * \star \star \\
(0.294)\end{array}$ & $\begin{array}{c}1.038^{\star \star \star} \\
(0.298)\end{array}$ & $\begin{array}{c}1.009 * \star \star \\
(0.302)\end{array}$ & $\begin{array}{l}0.843^{\star \star} \\
(0.356)\end{array}$ & $\begin{array}{c}1.185^{\star \star \star} \\
(0.321)\end{array}$ & $\begin{array}{c}1.056^{\star * *} \\
(0.315)\end{array}$ & $\begin{array}{c}1.111^{\star * *} \\
(0.323)\end{array}$ & $\begin{array}{c}0.553 \\
(0.412)\end{array}$ & $\begin{array}{c}1.126^{\star \star \star} \\
(0.330)\end{array}$ \\
\hline Poverty rate $1995-96$ & $\begin{array}{c}0.980 * \star * \\
(0.291)\end{array}$ & $\begin{array}{c}0.961^{\star * *} \\
(0.310)\end{array}$ & $\begin{array}{c}0.899 * \star \star \\
(0.295)\end{array}$ & $\begin{array}{c}0.886^{\star * *} \\
(0.288)\end{array}$ & & & & & \\
\hline Literacy rate 1991 & & & & & $\begin{array}{c}-0.022^{\star \star *} \\
(0.006)\end{array}$ & $\begin{array}{c}-0.022^{\star * *} \\
(0.006)\end{array}$ & $\begin{array}{c}-0.021 \text { *** } \\
(0.006)\end{array}$ & $\begin{array}{c}-0.023^{\star \star \star} \\
(0.005)\end{array}$ & $\begin{array}{c}-0.021^{\star * *} \\
(0.006)\end{array}$ \\
\hline Caste fractionalization & $\begin{array}{c}-0.236 \\
(0.790)\end{array}$ & & & & $\begin{array}{l}-0.495 \\
(0.901)\end{array}$ & & & & \\
\hline High caste dominance dummy & & $\begin{array}{c}0.085 \\
(0.132)\end{array}$ & & & & $\begin{array}{l}0.264^{\star} \\
(0.139)\end{array}$ & & & \\
\hline Linguistic fractionalization & & & $\begin{array}{c}-0.220 \\
(0.301)\end{array}$ & & & & $\begin{array}{c}-0.225 \\
(0.314)\end{array}$ & & \\
\hline Proportion speaking Nepali & & & & $\begin{array}{c}0.326 \\
(0.278)\end{array}$ & & & & $\begin{array}{l}0.759 * * \\
(0.310)\end{array}$ & \\
\hline Linguistic polarization & & & & & & & & & $\begin{array}{c}-0.164 \\
(0.287)\end{array}$ \\
\hline Observations & 70 & 70 & 70 & 70 & 73 & 73 & 73 & 73 & 73 \\
\hline R-squared & 0.40 & 0.41 & 0.41 & 0.41 & 0.40 & 0.43 & 0.40 & 0.46 & 0.40 \\
\hline
\end{tabular}

Robust standard errors in parentheses

* significant at $10 \%$; ** significant at $5 \%$; *** significant at $1 \%$

Regressions are based on district level data, excluding the districts of Rolpa and Rukum.

See Data Appendix for sources and descriptions of all variables. 
Appendix Table A3: Other robustness checks

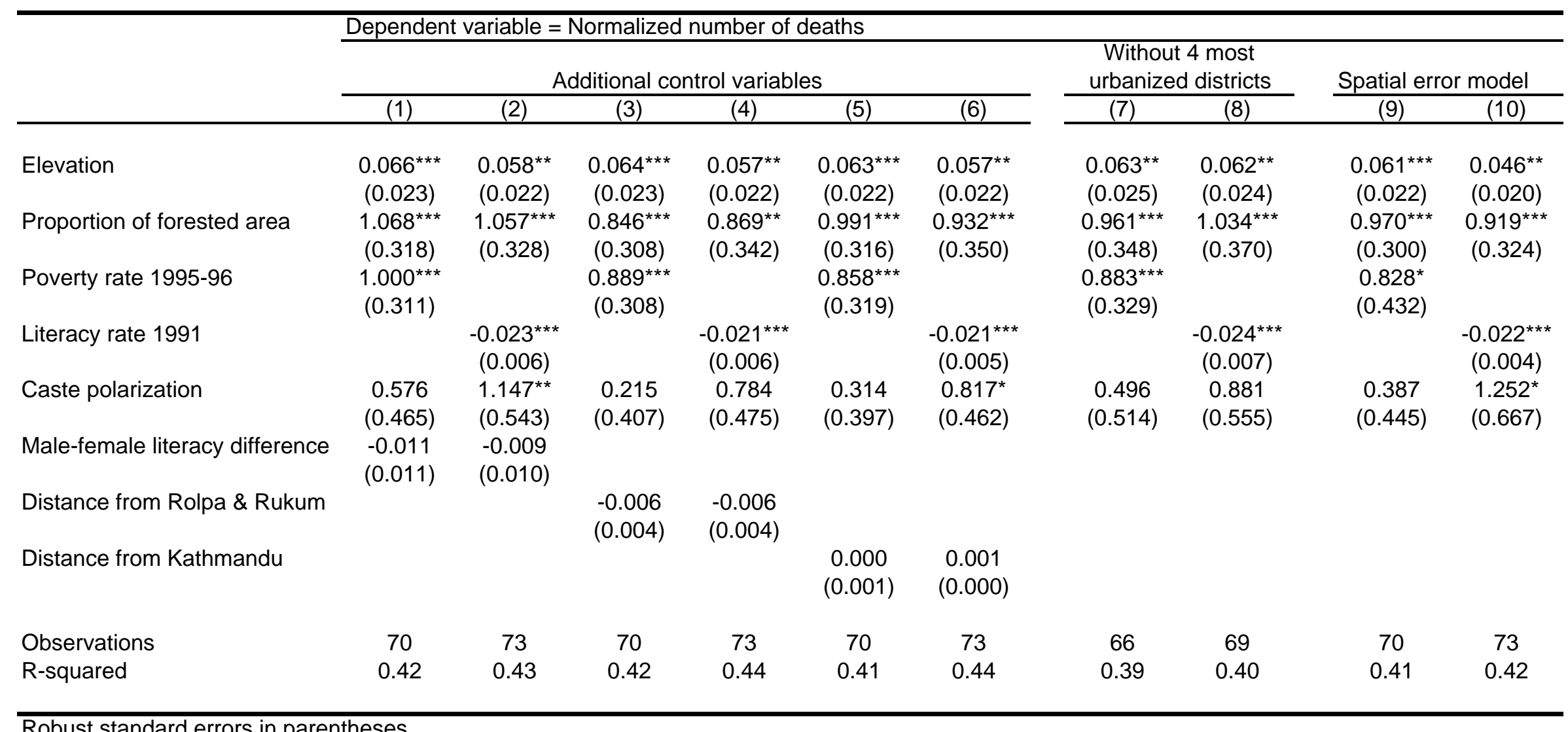

Robust standard errors in parentheses

* significant at 10\%; ** significant at 5\%; ** significant at $1 \%$

Regressions are based on district level data, excluding the districts of Rolpa and Rukum.

See Data Appendix for sources and descriptions of all variables.

Columns (5) and (6) exclude the districts of Kathmandu, Lalitpur, Bhaktapur and Kaski. 
Appendix Table A4: Relationship between poverty and caste polarization

\begin{tabular}{|c|c|c|c|}
\hline & \multicolumn{3}{|c|}{ Dependent variable = Poverty rate } \\
\hline & (1) & (2) & (3) \\
\hline Caste polarization & $\begin{array}{c}0.540 * \star * \\
(0.167)\end{array}$ & $\begin{array}{c}0.386^{*} \\
(0.219)\end{array}$ & $\begin{array}{c}0.488^{\star \star \star} \\
(0.174)\end{array}$ \\
\hline Elevation & & $\begin{array}{c}0.002 \\
(0.010)\end{array}$ & $\begin{array}{c}-0.001 \\
(0.008)\end{array}$ \\
\hline Proportion of forested area & & $\begin{array}{c}0.311^{*} \\
(0.165)\end{array}$ & $\begin{array}{c}0.192 \\
(0.130)\end{array}$ \\
\hline Literacy rate 1991 & & & $\begin{array}{c}-0.012^{\star * \star} \\
(0.002)\end{array}$ \\
\hline Observations & 70 & 70 & 70 \\
\hline R-squared & 0.10 & 0.15 & 0.45 \\
\hline
\end{tabular}

Robust standard errors in parentheses

* significant at 10\%; ** significant at 5\%; *** significant at $1 \%$

Regressions are based on district level data.

All regressions exclude the districts of Rolpa and Rukum.

See Data Appendix for sources and descriptions of all variables. 


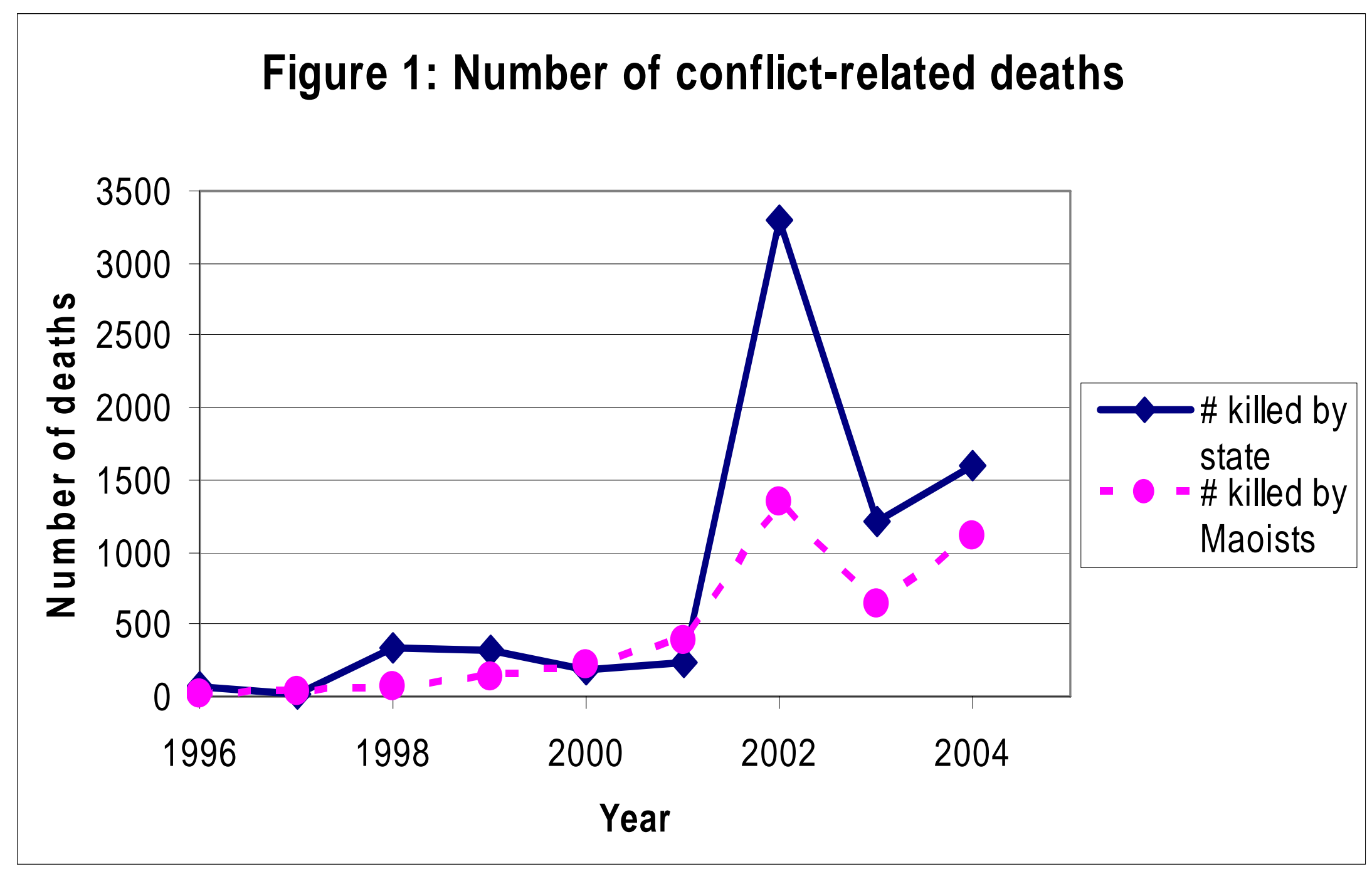




\section{Figure 2: Map of conflict intensity (number of deaths per 1000 population)}

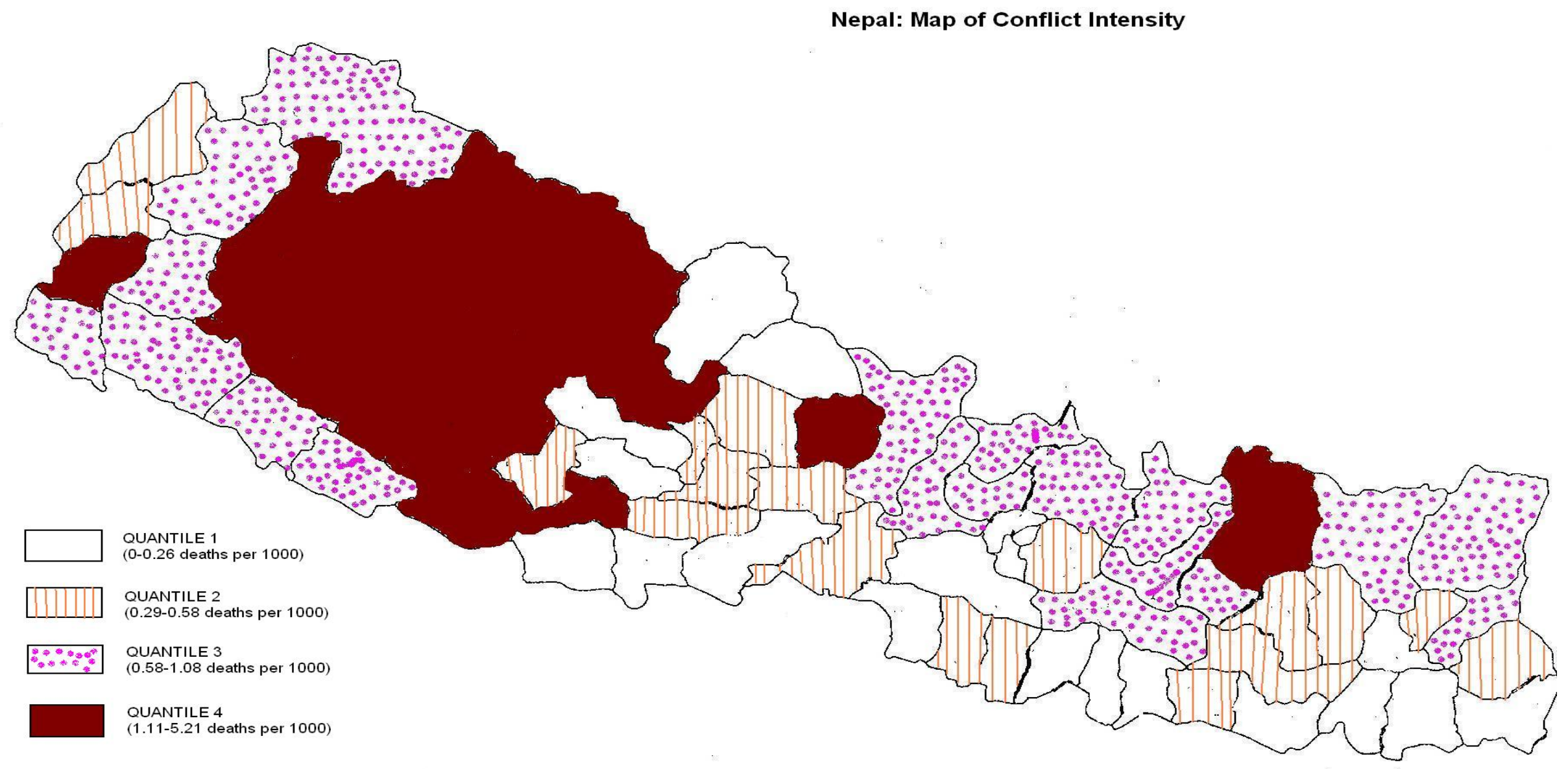


Figure 3: Geographical spread of conflict over time
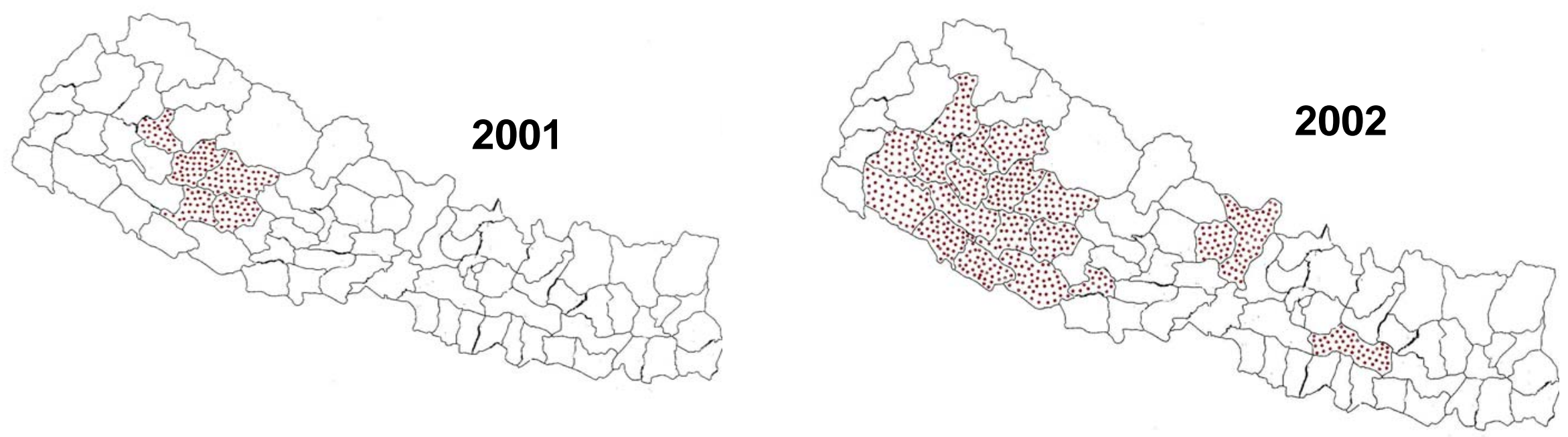

Districts reporting more than 100 deaths since 1996
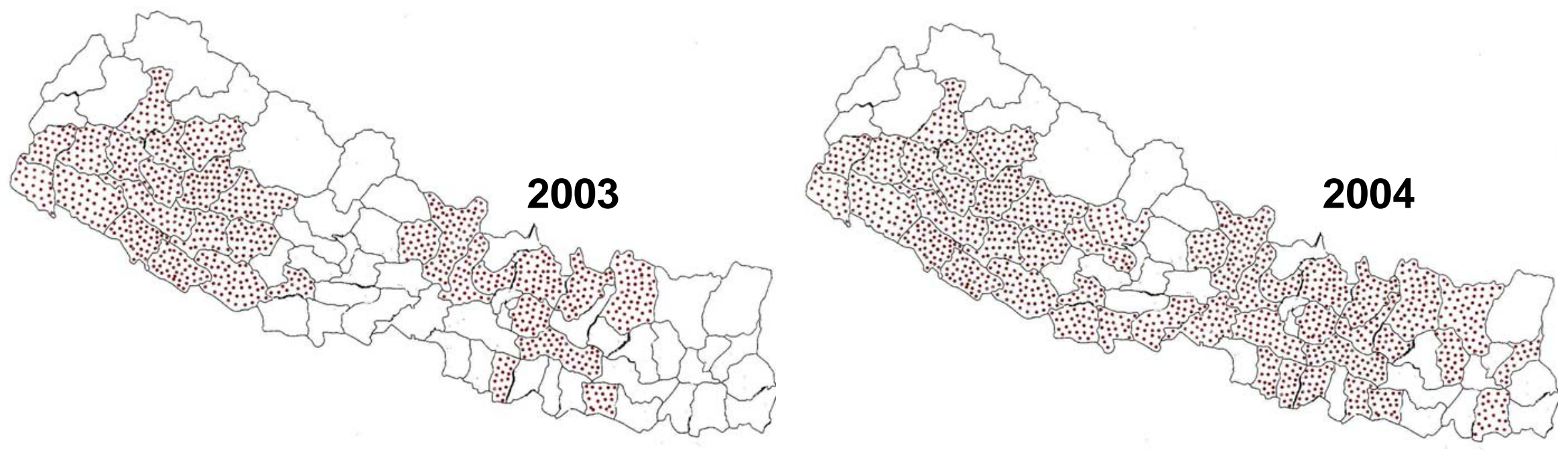


\section{Figure 4A: Evolution of Maoist-caused deaths by poverty quartile}

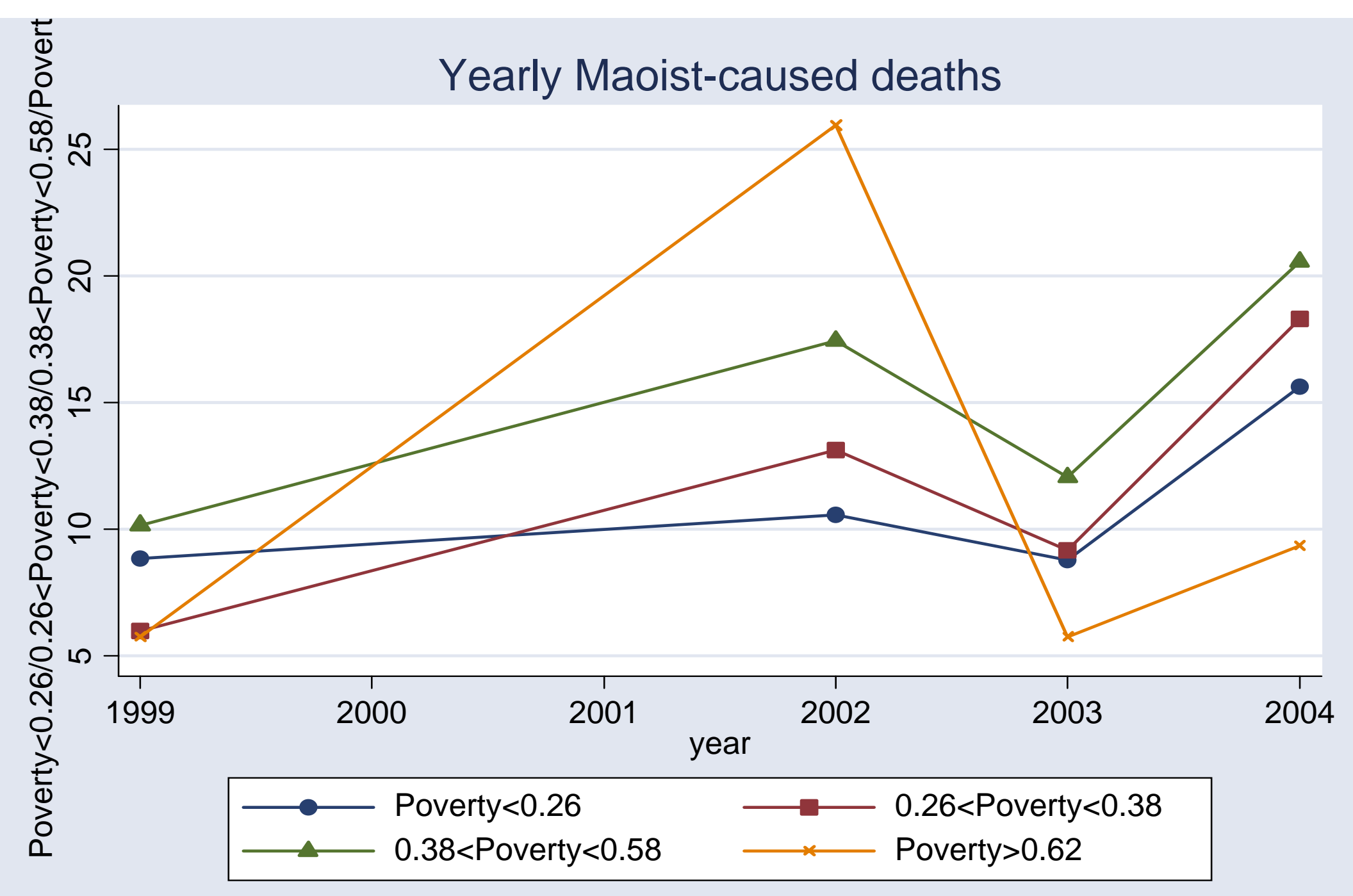


Figure 4B: Evolution of State-caused deaths by poverty quartile

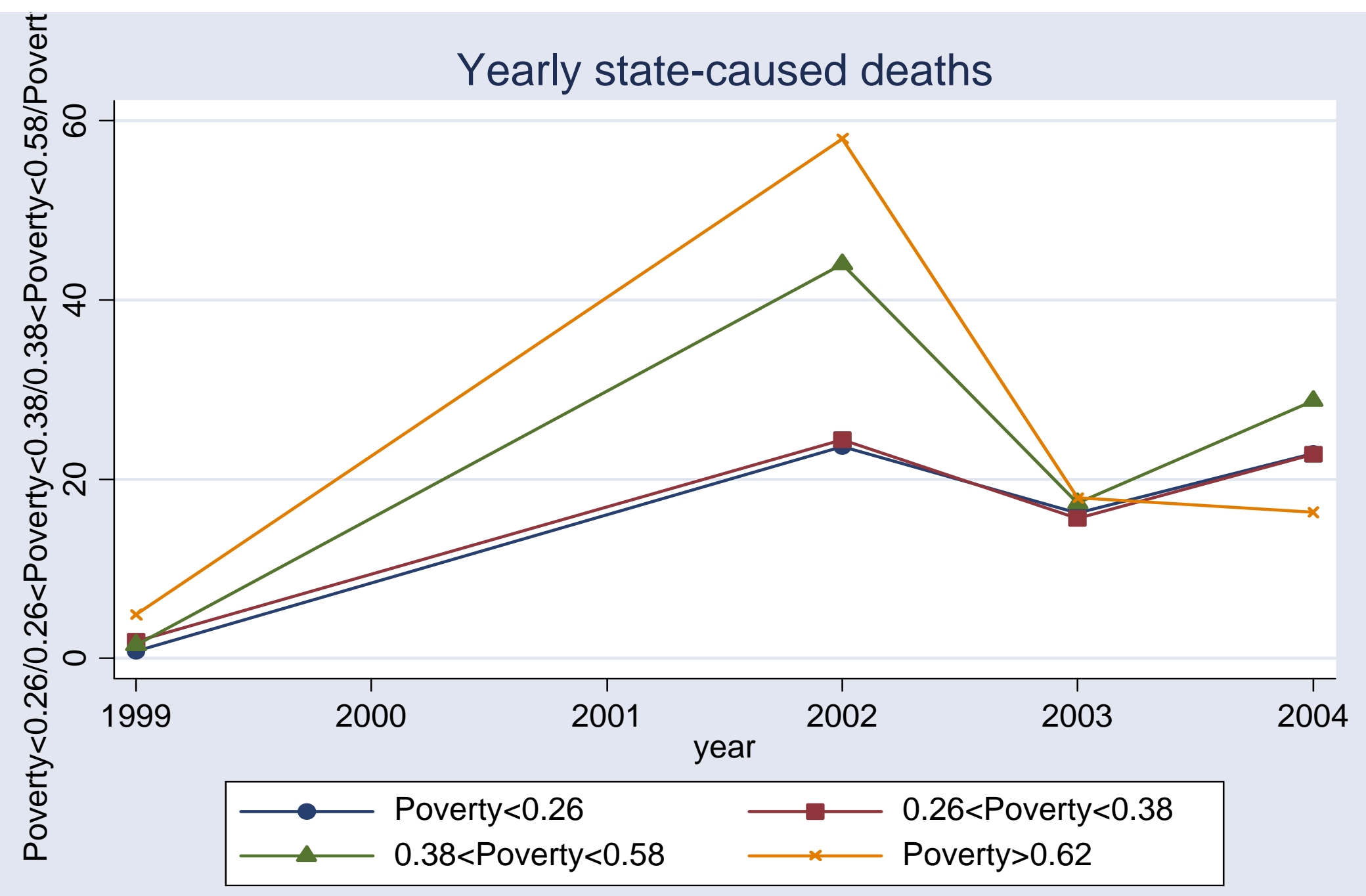

